\title{
A New Role for the Cell Adhesion Molecule L1 in Neural Precursor Cell Proliferation, Differentiation, and Transmitter-Specific Subtype Generation
}

\author{
Marcel Dihné, ${ }^{1}$ Christian Bernreuther, ${ }^{1}$ Mirjam Sibbe, ${ }^{1}$ Werner Paulus, ${ }^{2}$ and Melitta Schachner ${ }^{1}$ \\ ${ }^{1}$ Zentrum für Molekulare Neurobiologie Hamburg, Universität Hamburg, D-20251 Hamburg, Germany, and ${ }^{2}$ Institut für Neuropathologie, Universität \\ Münster, D-48129 Münster, Germany
}

\begin{abstract}
Adhesion molecules play important roles in the development and regeneration of the CNS and PNS. We found that the immunoglobulin superfamily recognition molecule L1 influences proliferation and differentiation of neural precursor cells. Substrate-coated L1 reduced proliferation of precursor cells in a dose-dependent manner and increased neuronal and decreased astrocytic differentiation when compared with poly-L-lysine or laminin substrates. Enhancement of neuronal differentiation was more effective if L1 was offered via the cell surface of transfected fibroblasts compared with substrate-coated purified L1. Furthermore, L1 decreased cholinergic-subtype differentiation and accelerated GABAergic differentiation of precursor cell-derived neurons in comparison with poly-L-lysine or laminin. Generation of dopaminergic neurons was not influenced by L1. Experiments with precursor cells generated from L1-deficient mice indicate that L1 acts via heterophilic interaction on proliferation and differentiation of L1-negative precursor cells and via a homophilic or L1 coreceptor-mediated interaction on maturation of precursor cell-derived L1-positive neurons. Clonal analysis revealed that L1 equally inhibits proliferation of monopotential, bipotential, and multipotential precursor cells, but selectively enhances neuronal differentiation of multipotential and bipotential neuron-astrocyte precursors. Our observations support a new role for L1 or L1 ligands in neural precursor cell proliferation and differentiation.
\end{abstract}

Key words: acetylcholine; adrenalin; cell adhesion molecules; differentiation; dopamine; GABA; L1; neural stem cells; proliferation

\section{Introduction}

Neural precursor cells have been the focus of increased attention over recent years because of their potential in cell replacement and gene therapy in the adult brain of vertebrates (Brüstle et al., 1997, 1999; Rao, 1999; Bjorklund and Lindvall, 2000; Morshead and van der Kooy, 2001; Kintner, 2002). Germinative zones harboring those stem cells in the adult brain of rodents and primates are sources for neurogenesis throughout life (Gage, 1998). After transplantation into the CNS, neural precursor cells generated from different origins of the brain and propagated in vitro are able to rescue damaged host tissue and differentiate into appropriate site-specific cells for tissue replacement (Campbell et al., 1995; Lundberg et al., 1997; Bjorklund, 1999, 2000). In vitro and in vivo studies revealed different ligands and their receptors as well as different transcription factors to be involved in regulating precursor cell proliferation and differentiation into multiple lineages (Morrison, 2001). Despite those advances, information about the cellular and molecular signals that influence precursor cells in

Received April 7, 2003; revised May 27, 2003; accepted May 30, 2003.

This work was supported by the Deutsche Forschungsgemeinschaft (Di 881/1-1; Scha 185/32-1). We are grateful to Masaru Okabe for providing the transgenic mouse expressing EGFP, to Michael Kutsche and Peggy Putthoff for providing the L1-deficient mouse, and to Melanie Richter for generating a polyclonal L1 antibody. We are particularly grateful to Marius Ader and Udo Bartsch for helpful discussions and critical comments on this manuscript.

Correspondence should be addressed to Dr. Marcel Dihné, Zentrum für Molekulare Neurobiologie Hamburg, Martinstrasse 52, 20246 Hamburg, Germany. E-mail: marcel.dihne@zmnh.uni-hamburg.de.

Copyright $\odot 2003$ Society for Neuroscience $\quad$ 0270-6474/03/236638-13\$15.00/0 vitro and in vivo or in the host environment after a lesion remains incomplete. It is plausible to assume that in addition to the factors mentioned above, recognition molecules at the cell surface and in the extracellular matrix play important roles in precursor cell biology. The neural recognition molecule L1 is such a potentially important molecule, because it mediates cell interactions during development and in the adult nervous system (Schachner, 1989). L1 has been shown to play important roles in neuronal migration and survival, neurite extension and fasciculation, axon guidance, regeneration, and synaptic plasticity in vitro and in vivo (Hortsch, 1996, 2000; Dahme et al., 1997; Brümmendorf et al., 1998). L1 is expressed predominantly by postmitotic neurons in the CNS and by nonmyelinating Schwann cells in the PNS where it also contributes efficiently to regrowth of axons by homophilic interactions with Schwann cells and enhances myelination. Furthermore, a reduced number of neurons in the hippocampus of adult L1-deficient mice raises the possibility that L1 may be involved in neurogenesis (Demyanenko et al., 1999). Because of the ability of L1 to influence brain development and behavior in a beneficial manner, we hypothesized that L1 may play a crucial role in influencing the differentiation of neural precursor cells. We therefore presented L1 in substrate and cell-bound form to neural precursor cells. Here we report that L1 reduces heterophilically the proliferation of monopotential, bipotential, and multipotential neural precursor cells. In addition, L1 enhances selectively the differentiation of multipotential and bipotential neuron-astro- 
cyte precursors into neurons by heterophilic interactions and modifies the neurotransmitter-specific subtype of precursor cellderived neurons via homophilic or L1 coreceptor-mediated binding mechanisms.

\section{Materials and Methods}

Neural precursor cells. All experiments were approved by the University and State of Hamburg Animal Care Committees. Fourteen-day-old embryos from wild-type C57BL/6J mice or C57BL/6J mice ubiquitously expressing enhanced green fluorescent protein (GFP) under the control of the chicken actin promotor were used (Okabe et al., 1997). Lateral and medial ganglionic eminences were removed from embryos and dissociated mechanically with a fire-polished Pasteur pipette in DMEM/F-12 (1:1) (Biochrom, Berlin, Germany) containing glucose (0.6\%) (Merck, Darmstadt, Germany), glutamine (2 mm) (Invitrogen, Karlsruhe, Germany), sodium bicarbonate (3 mM) (Invitrogen), HEPES buffer (5 mм) (Merck), and $20 \mu \mathrm{l} / \mathrm{ml} \mathrm{B27} \mathrm{(Invitrogen).} \mathrm{For} \mathrm{generation} \mathrm{and} \mathrm{expansion}$ of neurospheres, epidermal growth factor (EGF) (PreproTech, Rocky Hill, NY) and fibroblast growth factor-2 (FGF-2) (PreproTech) were added to a final concentration of $10 \mathrm{ng} / \mathrm{ml}$ each. The initial seeding density was 200,000 cells $/ \mathrm{ml}$. After $6 \mathrm{~d}$ in vitro, cells were passaged for the first time with a seeding density of $50,000 \mathrm{cell} / \mathrm{ml}$. From the first passage onward, neurospheres were passaged every fifth day. Vital cells were determined by $0.5 \%$ Trypan blue dye (Invitrogen) exclusion. Proliferation and differentiation experiments were performed with EGF-FGFgenerated neurospheres between passages 3 and 6 .

Generation of L1-deficient neural precursor cells. For generation of L1deficient precursor cells, the C57BL/6J L1/tTA knock-in mutant was used. In this mutant, expression of L1 was abolished by insertion of a tetracycline-controlled transactivator (tTA) (Gossen and Bujard, 1992) into the second exon of the L1 gene (thereafter called fL1 ${ }^{-/ y}$ ) (M. Kutsche and M. Schachner, unpublished data). The null mutation of these mice was confirmed by immunoblot analysis of each embryo derived from the crossing of $\mathrm{fL}^{+/-}$female and C57BL/6J male mice. Generation of $\mathrm{fL}^{-/ y}$ neurospheres was identical to that from wild-type or GFP ${ }^{+}$ neurospheres.

Purification of L1 from mouse brain homogenate. The cell adhesion molecule L1 was immunoaffinity purified from brain homogenate of adult C57BL/6J mice as described by Rathjen and Schachner (1984).

Substrate-coating of L1, laminin, and poly-L-lysine. For coating of polyL-lysine (PLL), coverslips were washed overnight in 100\% ethanol. After they were washed five times in distilled water, coverslips were incubated overnight at $4^{\circ} \mathrm{C}$ in $0.01 \%$ PLL (Sigma-Aldrich, Deisenhofen, Germany). After coating, coverslips were washed three times in distilled water and air-dried. For coating of laminin (Sigma) or L1, PLL-precoated coverslips were treated overnight at $4^{\circ} \mathrm{C}$ with $100 \mu \mathrm{l}$ of coating solution containing laminin or L1 in HBSS (PAA Laboratories GmbH, Linz, Austria) at the concentrations indicated. Before stem cells were seeded, coated coverslips were washed two times in PBS.

Production of L1-expressing fibroblasts. To produce L1-expressing fibroblasts, we used the MEF/3T3 Tet-Off Cell Line (Clontech, Palo Alto, $\mathrm{CA}$ ), which contains the regulator plasmid of the Tet-Off-System coding for the tTA and for neomycin resistance. For L1 expression, the pBI-2 expression plasmid carrying a bidirectional tTA-responsive promotor that drives both the luciferase marker gene and the gene of interest was used (Baron et al., 1995). L1 cDNA was isolated from pJG2-L1 and inserted into pBI-2 (Senner et al., 2002). For generating stable cell lines, the pkoSelectPuro (pkoSP) plasmid (Stratagene, La Jolla, CA) carrying a puromycin resistance gene was used. Cotransfection of pBI-L1 and pkoSP at a ratio of 4:1 was performed by electroporation (400 V, time constant $100 \mu \mathrm{sec}, 1$ pulse) (Bio-Rad Gene Pulser, Munich, Germany). Selection of resistant clones was achieved by adding $4 \mu \mathrm{g}$ of puromy$\mathrm{cin} / \mathrm{ml}$ culture medium. Clones were tested for the tetracycline derivative doxycycline- (Sigma) dependent regulation of luciferase activity and L1 expression. L1 expression and luciferase activity were seen without adding doxycycline, whereas expression of $\mathrm{L} 1$ and luciferase activity were totally suppressed after addition of doxycycline $(1 \mu \mathrm{g} / \mathrm{ml})$ for $7 \mathrm{~d}$, the earliest time point tested after addition of doxycycline.
Measurement of luciferase activity. After lysis buffer (25 mm Tris, $\mathrm{pH}$ 7.8, 2 mм dithiothreitol, $2 \mathrm{~mm}$ diaminocyclohexanetetra-acetic acid, 10\% glycerol, $1 \%$ Triton $\mathrm{X}-100$ ) was added, cells were frozen at $-20^{\circ} \mathrm{C}$ for 5 min. After thawing, cells were centrifuged for $15 \mathrm{sec}$ at $12,000 \times \mathrm{g}$. Ten microliters of supernatant were mixed with $250 \mu \mathrm{l}$ of assay solution containing $25 \mathrm{~mm}$ glycerol and $15 \mathrm{~mm} \mathrm{MgSO}_{4}$. Immediately after adding $0.125 \mathrm{~mm}$ D-luciferin (Sigma), which is converted by luciferase to the fluorescent end product oxyluciferin, flashes of light generated by this reaction were measured with a luminometer (Lumat LB 9501, Berthold, Bad Wildbad, Germany).

Immunoblotting. Nontransfected, parental $\left(\mathrm{L}^{-}\right)$, or L1-transfected $\left(\mathrm{L}^{+}\right)$fibroblasts were lysed with buffer containing $50 \mathrm{~mm}$ Tris, $\mathrm{pH}$ 7.4, $150 \mathrm{~mm} \mathrm{NaCl}, 1 \%$ Nonidet P40, $1 \mathrm{~mm} \mathrm{Na}_{2} \mathrm{P}_{2} \mathrm{O}_{7}, 1 \mathrm{~mm} \mathrm{NaF}, 1$ mm EDTA, $2 \mathrm{mM} \mathrm{NaVO}_{4}$, and $2 \%$ Complete Protease inhibitor (Roche Biochemicals, Mannheim, Germany). Total protein was measured using the BCA Protein Assay Kit (Pierce, Rockford, IL). Proteins were separated by SDSPAGE ( $8 \%$ gels) by loading $3 \mu \mathrm{g}$ of protein in each lane and blotted onto nitrocellulose membranes (Schleicher \& Schuell, Dassel, Germany). After the membranes were blocked with $3 \%$ milk powder, L1 was detected after incubation with a polyclonal rabbit L1 antibody (1:4000) (kindly provided by Melanie Richter, Zentrum für Molekulare Neurobiologie Hamburg, Hamburg, Germany) at $4^{\circ} \mathrm{C}$ overnight and with appropriate horseradish peroxidase-conjugated secondary antibody using an ECL detection kit (Amersham Biosciences, Braunschweig, Germany).

Generation of a fibroblast monolayer. Parental and L1-transfected murine embryonic fibroblasts were expanded in DMEM high glucose (Biochrom) containing $10 \%$ fetal bovine serum (TET system approved, Clontech) and $200 \mathrm{~mm}$ glutamine (PAA). For collection of adherent cells, they were trypsinized with $0.05 \%$ trypsin/EDTA (PAA Laboratories $\mathrm{GmbH}$, Austria). Fibroblasts were seeded onto $15 \mathrm{~mm}$ glass coverslips placed into 12 -well plates at a density of 100,000 cells/ml ( $1 \mathrm{ml}$ per well). At confluency after $6 \mathrm{~d}$, fibroblasts were treated with $10 \mu \mathrm{g} / \mathrm{ml}$ mitomycin-C (Roth, Karlsruhe, Germany) for $3 \mathrm{hr}$ at $37^{\circ} \mathrm{C}$ to inhibit proliferation.

Attachment, proliferation, and differentiation of neural precursor cells. Attachment of dissociated precursors was assessed by cell counting 12 or $24 \mathrm{hr}$ after plating on coverslips coated with different concentrations of substrates. For assessment of overall proliferation of neural precursor cells and for determination of the proportion of proliferating neuronal precursor cells, bromodeoxyuridine (BrdU) (10 $\mu \mathrm{mol}$; Sigma) was administered in EGF-FGF-containing culture medium $8 \mathrm{hr}$ before cells were fixed with $4 \%$ paraformaldehyde. To detect neuronal precursor cells, double-immunolabeling for BrdU and protein gene product 9.5 (pGp 9.5) as a marker for young neurons was used. Antibodies to pGp 9.5 are from rabbit and label the same immature neurons as $\beta$-tubulin antibodies (this was confirmed by double immunocytochemistry for $\beta$-tubulin and pGp 9.5), which are from mouse and therefore cannot be used for double immunolabeling with mouse BrdU antibodies. For assessment of differentiation, neurospheres were mechanically dissociated and plated at a density of $10,000,20,000$, or 50,000 cells/ml onto $15 \mathrm{~mm}$ glass coverslips coated with PLL, laminin, $\mathrm{L} 1$, or $\mathrm{L}^{-}{ }^{-}$and $\mathrm{L}^{+}{ }^{+}$fibroblasts. This procedure led to equally distributed and well separated single cells that proliferated under the influence of EGF-FGF until reaching confluency. The concentrations of the coating solutions for proteins ranged from 5 to $50 \mu \mathrm{g} / \mathrm{ml}$ for laminin and 1 to $15 \mu \mathrm{g} / \mathrm{ml}$ for L1. Control experiments with heat-inactivated $\mathrm{L} 1$ protein $\left(70^{\circ} \mathrm{C}\right.$ for $\left.15 \mathrm{~min}\right)$ were also performed. For differentiation experiments, precursor cells were first maintained in an undifferentiated state for $5 \mathrm{~d}$ after plating in EGF-FGFcontaining serum-free culture medium. Growth factors were then removed (omitting any other additives to the medium), and precursor cells were then allowed to differentiate for an additional $5 \mathrm{~d}$. Ten days after plating, coverslips were washed in PBS, and cells were fixed for $30 \mathrm{~min}$ in 4\% paraformaldehyde in PBS.

For immunocytochemistry with cell type-specific markers, cells were washed in PBS and treated with $0.1 \%$ bovine serum albumin (Sigma) in PBS for $40 \mathrm{~min}$. Primary antibodies, used at $4^{\circ} \mathrm{C}$ overnight, were monoclonal mouse antibodies to $\beta$-tubulin (Tuj1) (1:400; Sigma), GFAP (1: 1000; Sigma), nestin (1:50; Developmental Studies Hybridoma Bank, Iowa City, IA), myelin-associated-glycoprotein (MAG; 1:10) (Poltorak et 
al., 1987), and a monoclonal rat antibody to myelin-basic protein (MBP) (1:200; Chemicon), and polyclonal rabbit antibodies to GFAP (1:1000; Dako, Carpinteria, CA), pGp 9.5 (1: 500; Biotrend, Cologne, Germany), L1 (1:50), tyrosine hydroxylase (TH) (1:100; Chemicon), glutamate decarboxylase (GAD 65) (1:20; Chemicon), and a polyclonal goat antibody to vesicular acetylcholine transporter (VAChT) (1:1500; Chemicon). For detection of first antibodies, appropriate cyanine (Cy2), indocarbocyanine (Cy3), indodicarbocyanine (Cy5) (Dianova, Hamburg, Germany), and ultraviolet (UV) (Molecular Probes, PoortGebouw, The Netherlands) coupled secondary antibodies were used. Some coverslips were counterstained for $10 \mathrm{~min}$ with $50 \mu \mathrm{g} / \mathrm{ml}$ DAPI (Sigma) for staining of cell nuclei. For BrdU staining, DNA was denatured with $70 \%$ ethanol for 5 min at room temperature and with $2.4 \mathrm{M} \mathrm{HCl}$ for $10 \mathrm{~min}$ at $37^{\circ} \mathrm{C}$. Monoclonal mouse antibody to $\operatorname{BrdU}\left(1: 200\right.$; Sigma) was administered overnight at $4^{\circ} \mathrm{C}$. Reliability of all primary antibodies was monitored by including appropriate positive controls in each experiment. For negative controls, primary antibody was omitted.

Assessment of cell death. To determine cell death by the terminal deoxynucleotidyl transferase-mediated biotinylated UTP nick end labeling (TUNEL) method, the In Situ Cell Death Detection Kit (Roche Biochemicals) was used according to the manufacturer's instructions.

Clonal analysis. To achieve clonal growth from single neurospherederived precursor cells, $\mathrm{GFP}^{+}$precursors were plated at low density (1 cell $/ 6 \mathrm{~mm}^{2}$ ) into $35 \mathrm{~mm} \emptyset$ cell culture dishes coated with poly-L-lysine $(0.01 \%)$, laminin $(20 \mu \mathrm{g} / \mathrm{ml})$, or L1 $(6 \mu \mathrm{g} / \mathrm{ml})$. For complete dissociation, neurospheres were treated with undiluted Accutase (PAA) for $10 \mathrm{~min}$ at $37^{\circ} \mathrm{C}$ before triturating. Two hours after seeding, only well dissociated single $\mathrm{GFP}^{+}$cells were marked by scratching the bottom of the culture dishes. Because we could not achieve clonal growth at cell concentrations under 90 cells $/ 6 \mathrm{~mm}^{2}$, we established a mixed cell culture system with $\mathrm{GFP}^{+}$precursors at 1 cell $/ 6 \mathrm{~mm}^{2}$ and "supporter" GFP ${ }^{-}$precursors at 125 cells cells $/ 6 \mathrm{~mm}^{2}$. Clonal analysis was performed only with GFP ${ }^{+}$ clones. This technique provides a cell culture system in which single precursor cell clones can be observed within their normal environment. Plating single cells at low density without "supporter" cells could lead to a selective survival of only certain precursors that do not reflect the diversity of precursor cells. Preliminary experiments demonstrated that $3 \mathrm{~d}$ of expansion time in the presence of EGF and FGF were optimal to obtain clearly isolated $\mathrm{GFP}^{+}$clones situated within a population of $\mathrm{GFP}^{-}$cells. Only GFP ${ }^{+}$clones separated by a distance of at least $500 \mu \mathrm{m}$ were considered for clonal analysis to rule out the possibility of interclonal migration of cells. Precursor cells were allowed to differentiate without growth factors for $10 \mathrm{~d}$ after the $3 \mathrm{~d}$ expansion period. This procedure reduced the proportion of nestin ${ }^{+}$immature precursor cells to $\sim 5-10 \%$ in comparison with a differentiation period of only $5 \mathrm{~d}$ when $\sim 45 \%$ of all cells were still nestin ${ }^{+}$. Only $\mathrm{GFP}^{+}$clones were considered for clonal analysis in which all cells could be classified as neuronal, astrocytic, or oligodendroglial. For this purpose, mixed cell cultures were triple labeled immunocytochemically by antibodies to $\beta$-tubulin for neurons, GFAP for astrocytes, and MBP for oligodendrocytes, using the appropriate secondary antibodies coupled to $\mathrm{Cy} 3$ (for $\beta$-tubulin), $\mathrm{Cy} 5$ (for GFAP), and UV (for MBP). Single clones were visualized by observation of GFP.

Cell counting and statistics. To measure the total populations of precursor cells, GFP ${ }^{+}$cells or DAPI ${ }^{+}$nuclei (e.g., in the case of $\mathrm{GFP}^{-}$precursor cells from L1-deficient mice) were counted. Control experiments were performed to check that all $\mathrm{GFP}^{+}$cells were also $\mathrm{DAPI}^{+}$and vice versa. Experiments were repeated with independent cultures at least three times in duplicate. For clonal analysis, four independent experiments were performed. On every coverslip, at least $200 \mathrm{GFP}^{+}$or DAPI $^{+}$cells were counted. Percentages of double-labeled cells (cell type-specific marker-GFP ${ }^{+}$or
- DAPI $^{+}$cells) were counted and averaged. SEM was calculated. Student's $t$ test was used for statistical evaluation.

\section{Results}

$\boldsymbol{\beta}$-tubulin-positive neurons but not undifferentiated neural precursor cells express L1

To verify whether the observation that L1 is expressed only on postmitotic neurons also applies for neurons derived from neural precursor cells, L1 immunocytochemistry was performed. Neurospheres and dissociated precursor cells under the influence of growth factors (EGF and FGF) were L1 negative. One day after initiating differentiation by growth factor withdrawal, some cells maintained on a PLL substrate were first detected to express L1 (Fig. $1 A-C$ ). Double immunocytochemistry with cell typespecific markers showed that L1 was expressed only by precursorderived $\beta$-tubulin ${ }^{+}$neurons. Also 3 and $5 \mathrm{~d}$ after initiating differentiation, nearly all $\mathrm{L} 1^{+}$cells were $\beta$-tubulin ${ }^{+}$.

\section{L1 inhibits neural precursor cell proliferation}

To determine precursor cell proliferation, nestin ${ }^{+}$cultures were maintained $8 \mathrm{hr}$ in BrdU, after growing for $6 \mathrm{~d}$ in the presence of growth factors. Percentages of $\mathrm{BrdU}^{+}$precursor cells were measured on substrate-coated L1 $(1-15 \mu \mathrm{g} / \mathrm{ml})$ and, for control, on laminin $(5-50 \mu \mathrm{g} / \mathrm{ml})$ or PLL. Offering L1 as a substrate was preferred over administration of L1 in solution because L1 as a substrate is more efficient than soluble L1 in enhancing neurite outgrowth or neuronal survival (Chen et al., 1999). Nevertheless, some experiments with soluble L1 were performed with similar results as obtained with substrate-coated L1. At concentrations of 1 or $3 \mu \mathrm{g} / \mathrm{ml}$, L1 did not affect proliferation of precursor cells, whereas at $6 \mu \mathrm{g} / \mathrm{ml}, \mathrm{L} 1$ led to a significant reduction of $\mathrm{BrdU}^{+}$ precursor cells to a level of $63 \pm 7.7 \%$ when compared with PLL substrate, which was set to $100 \%$ (Fig. $2 A, A^{\prime}, B, B^{\prime}, C$ ). At higher concentrations of substrate-coated $\mathrm{L} 1$, the number of $\mathrm{BrdU}^{+}$ precursor cells further decreased to $23 \pm 6.2 \%(15 \mu \mathrm{g} / \mathrm{ml} \mathrm{L1})$. Heat-inactivated L1 was ineffective in reducing proliferation (Fig. 2C). For laminin, no significant effects on precursor cell proliferation could be seen at all concentrations tested (Fig. 2D). In comparison with PLL, however, a slight tendency to higher proliferation rates could be detected.

To investigate whether proliferation rates depended on the day after plating and thus on different cell densities, dissociated precursor cells were maintained for $8 \mathrm{hr}$ in BrdU at different 


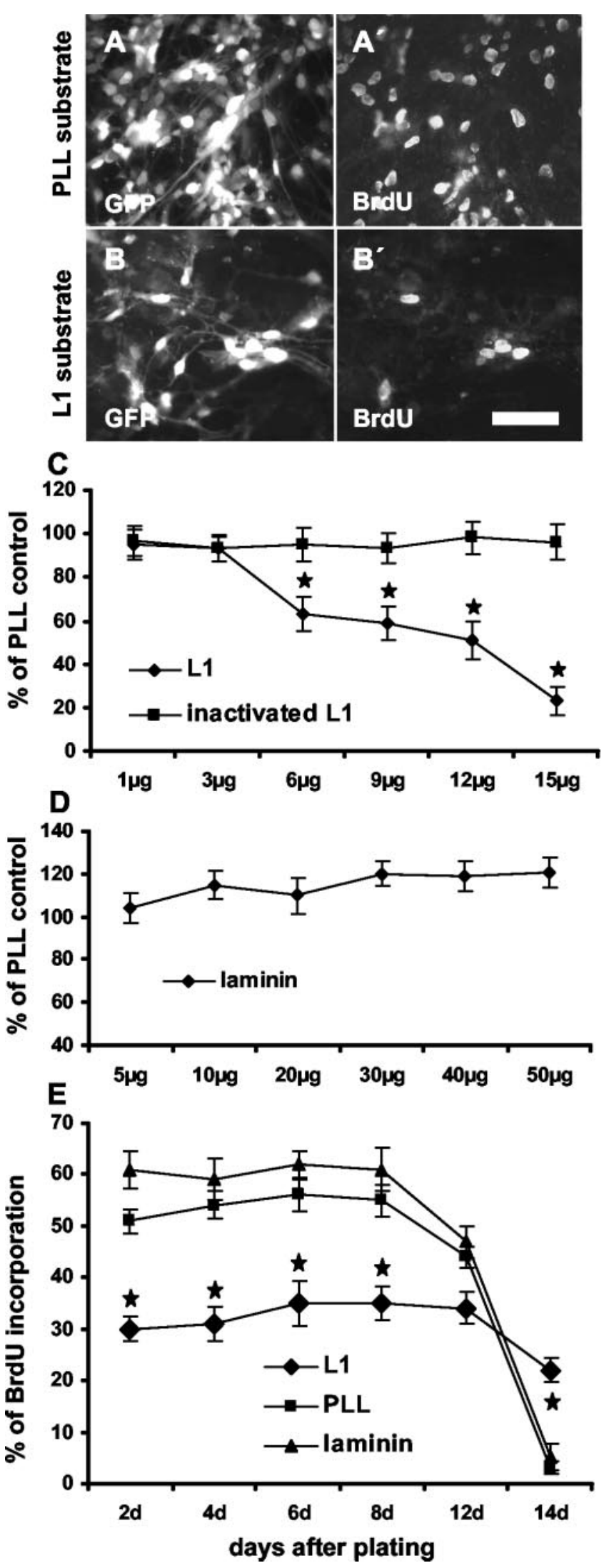

Figure 2. Substrate-coated L1 inhibits precursor cell proliferation. To measure the influence of different substrates on proliferation, dissociated precursor cells were plated on PLL, L1, or laminin substrates. Six days after plating, an $8 \mathrm{hr}$ BrdU pulse was administered, and the percentage of BrdU ${ }^{+}$cells was determined. Photomicrographs show more GFP ${ }^{+}$precursor cells on $\mathrm{PLL}(A)$ than on $\mathrm{L} 1(B)$ substrate. BrdU ${ }^{+}$cells are shown in corresponding figures of identical times after plating on L1 $(6 \mu \mathrm{g} / \mathrm{ml})$, laminin $(20 \mu \mathrm{g} / \mathrm{ml})$, or PLL substrate in the presence of growth factors (Fig. 2E). Until the eighth day after cell plating, BrdU incorporation always tended to be higher, although not significantly, on the laminin substrate $\left(59-62 \% \mathrm{BrdU}^{+}\right.$cells of all cells) than on the PLL substrate (51-56\% BrdU ${ }^{+}$cells of all cells). From the eighth day onward, after plating cells on PLL or laminin substrate, precursor cells decreased their proliferation, possibly because of the fact that they had reached $80-90 \%$ confluency. During the first $12 \mathrm{~d}$ after plating, precursor cells on L1 substrate proliferated significantly less when compared with PLL substrate, with only $30-35 \%$ of all cells incorporating BrdU. Probably because of the lower proliferation rate, precursor cells maintained on L1 substrate took a longer time to become confluent, and thus a decrease in proliferation was only seen $14 \mathrm{~d}$ after plating. When $\mathrm{L} 1$ was administered in solution at a concentration of $10 \mu \mathrm{g} / \mathrm{ml}$, a similar decrease in proliferation was seen as for substrate-coated L1 (data not shown).

L1 enhances neuronal differentiation of precursor cells To investigate whether L1 may affect differentiation of precursor cells, cultures growing on different substrates were monitored with cell type-specific markers by immunocytochemistry. Neurons were identified by the marker $\beta$-tubulin, mature astrocytes were identified by GFAP, and oligodendrocytes were identified by MAG. Undifferentiated precursor cells were identified by the marker nestin. Five days after the cells were seeded on PLL substrate in the presence of growth factors, most of the cells $(\sim 98 \%)$ were nestin ${ }^{+}$(Fig. $3 A, A^{\prime}$ ). Only occasionally, $\beta$-tubulin ${ }^{+}$, $\mathrm{GFAP}^{+}$, or $\mathrm{MAG}^{+}$cells were detectable $(<1 \%)$. After another $5 \mathrm{~d}$, when cells were maintained without growth factors, $45.0 \pm$ $2.6 \%$ were $\mathrm{GFAP}^{+}, 6.1 \pm 1.2 \%$ were $\beta$-tubulin ${ }^{+}$, and $3.0 \pm 0.9 \%$ were $\mathrm{MAG}^{+}$(Fig. $3 B-D$ ). Most of the cells that did not express any of these markers were nestin ${ }^{+}$.

When precursor cells were maintained on substrate-coated L1 $(6 \mu \mathrm{g} / \mathrm{ml})$ for $10 \mathrm{~d}$ (first $5 \mathrm{~d}$ in the presence of growth factors and then for another $5 \mathrm{~d}$ in their absence), the percentage of $\beta$-tubulin ${ }^{+}$neurons was increased by a factor of $2.0 \pm 0.12$ when compared with PLL substrate. The percentage of $\mathrm{GFAP}^{+}$astrocytes was reduced by $33 \pm 3.9 \%$ (Fig. $3 E-G$ ). Further increase in $\mathrm{L} 1$ concentration ( 9 and $12 \mu \mathrm{g} / \mathrm{ml}$ ) did not lead to further enhancement of neuronal or reduction of astrocytic differentiation. Because L1 inhibits proliferation of precursor cells and because differentiation of precursor cells could depend on cell density, differentiation on the different substrates was also tested at identical cell densities. To achieve this, before differentiation was started in the absence of growth factors, precursor cells on the L1 substrate were allowed to proliferate for an additional $3 \mathrm{~d}$ in the presence of growth factors to reach the same cell density as those cells maintained on PLL. After differentiation under these conditions, the number of $\beta$-tubulin ${ }^{+}$neurons was increased by a factor of $2.1 \pm 0.14$, and the number of GFAP ${ }^{+}$astrocytes was reduced by $35.3 \pm 2.3 \%$ when compared with PLL substrate. To

fields $\left(A^{\prime}, B^{\prime}\right)$. C, Percentages of all cells having incorporated BrdU when grown on substrates consisting of different concentrations of $L 1$ or heat-inactivated $L 1$ are shown in relation to $B r d U$ incorporation on PLL substrate, which was set to 100\%. D, Percentage of BrdU-labeled precursor cells on laminin substrate at different concentrations is shown in relation to BrdU incorporation on PLL substrate, which was set to $100 \%$. E, Time course of BrdU incorporation of precursor cells growing on the indicated substrates is shown. Decreasing amounts of BrdU ${ }^{+}$cells were detected at time points that precursor cells reached $80-90 \%$ confluency. Scale bar, $50 \mu \mathrm{m}$. ${ }^{*} p<0.05$ versus the corresponding time point on PLL substrate. 
further monitor the effect of L1 on neuronal differentiation as a function of plating density, precursor cells were plated at 10,000 and 20,000 cells $/ \mathrm{ml}$ instead of 50,000 cells $/ \mathrm{ml}$. On the L1 substrate, even under these lower plating densities, neuronal differentiation was increased by a factor of $2.1 \pm 0.13$, and differentiation of $\mathrm{GFAP}^{+}$cells was reduced by $30.5 \pm 3.6 \%$ when compared with the PLL substrate. Heat inactivation of L1 completely abolished these effects. Furthermore, when laminin was tested at concentrations from 5 to $50 \mu \mathrm{g} / \mathrm{ml}$, the differentiation pattern of precursor cells was not influenced when compared with cells maintained on PLL. The overall percentage of $\mathrm{MAG}^{+}$cells $(2.8 \pm 0.43 \%)$ on all substrates and at all concentrations tested did not change significantly.

Neural precursor cells attach equally well to different substrates

Because differences in proliferation and differentiation of precursor cells may be caused by differences in cell density that in turn may depend on differences in neural precursor cell attachment to different substrates, we investigated the efficiency of attachment of precursor cells after plating onto L1 substrate in comparison with PLL in the presence of growth factors. To allow complete attachment of cells and to control for the impact of different substrates on proliferation, two time points after seeding the cells were chosen: 12 and $24 \mathrm{hr}$. Substrate-coated L1 did not lead to a significant alteration of precursor cell attachment at coating concentrations from 3 to $15 \mu \mathrm{g} / \mathrm{ml}$ when compared with PLL (Table 1).

\section{L1 does not influence cell death}

To investigate whether L1 may influence the extent of precursor cell death, the percentage of TUNEL ${ }^{+}$cells in the total cell population was determined 5 and $10 \mathrm{~d}$ after the cells were seeded (first $5 \mathrm{~d}$ in the presence of growth factors and then for another $5 \mathrm{~d}$ in their absence). The number of total cells was assessed by DAPI staining, not by measuring GFP, because the green fluorescent labeling would have interfered with detection of labeled DNA by TUNEL staining. As mentioned before, total cell numbers by counting $\mathrm{GFP}^{+}$or $\mathrm{DAPI}^{+}$cells were not significantly different from each other. Percentages of TUNEL ${ }^{+}$cells were not different when precursor cells were maintained on PLL, L1, or laminin at different concentrations (Fig. $4 A, B$ ). On all substrates, the percentage of TUNEL ${ }^{+}$cells was between 5.9 and $8.5 \%$. We also investigated whether $\beta$-tubulin ${ }^{+}, \mathrm{GFAP}^{+}$, or $\mathrm{MAG}^{+}$cells showed altered TUNEL ${ }^{+}$fractions on different substrates. However, colabeling of TUNEL and cell type-specific markers was rarely found, and there were no differences between substrates. Most TUNEL ${ }^{+}$ cells were undifferentiated nestin ${ }^{+}$precursor cells, and the percentage of nestin ${ }^{+}-$TUNEL $^{+}$cells in the total cell population was not different on different substrates.
3 days after plating on PLL

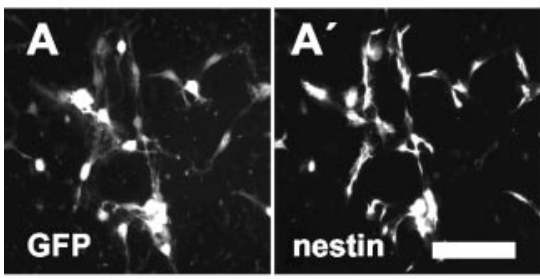

10 days after plating on PLL
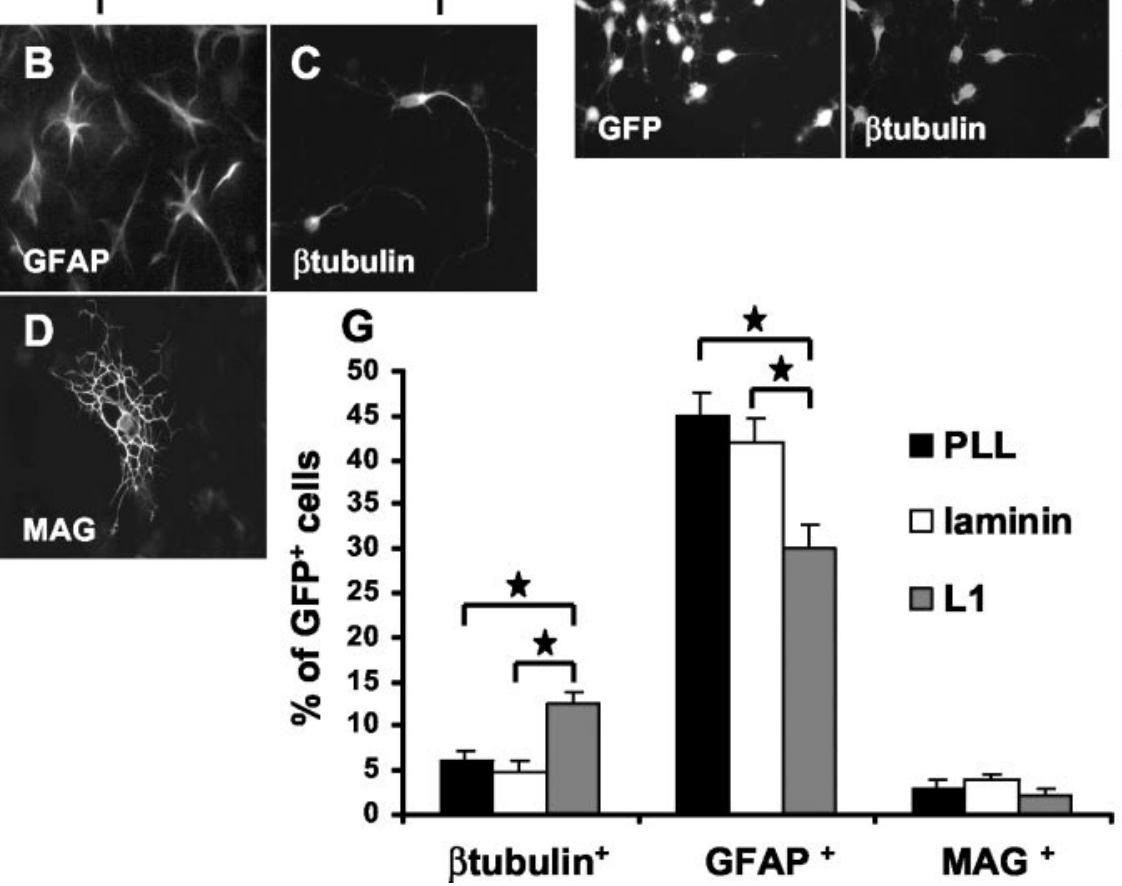

10 days after plating
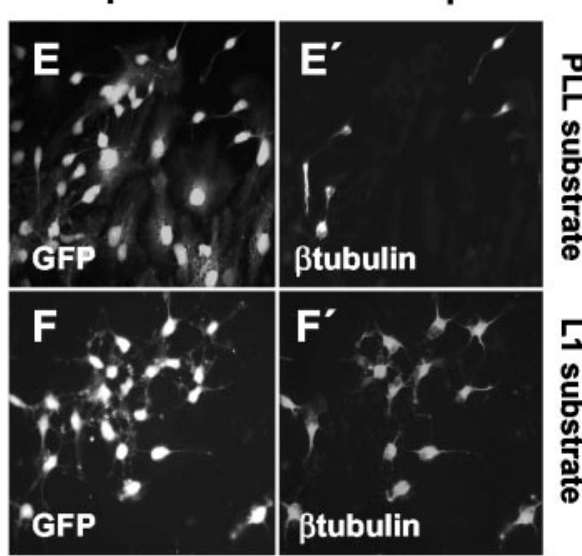

Figure 3. Substrate-coated L1 enhances neuronal yield after precursor cell differentiation. Three days after plating, in the cells $(B), \beta$-tubulin ${ }^{+}$cells $(C)$, and MAG ${ }^{+}$cells $(D)$ were found. On L1 $(6 \mu \mathrm{g} / \mathrm{ml})$ substrate, the 作 ${ }^{+}$neurons is increased when compared with PLL substrate $\left(E, E^{\prime}, F, F^{\prime}\right)$. On laminin $(20 \mu \mathrm{g} / \mathrm{ml})$ substrate the percentage of $\beta$-tubulin ${ }^{+}$neurons was similar when compared with PLL substrate $(G)$. Results concerning differentiation of precursor cells are summarized in $G$. Scale bar, $50 \mu \mathrm{m}$. Values are means + SEM. ${ }^{*} p<0.05$ versus the indicated bar.

Table 1. Attachment of precursor cells to substrate-coated L1 in relation to attachment to the PLL substrate

\begin{tabular}{lrr}
\hline $\begin{array}{l}\text { Concentration of L1 in } \\
\text { the coating solution }\end{array}$ & \multicolumn{2}{c}{$\%$ of PLL control } \\
\cline { 2 - 3 } & \multicolumn{1}{c}{$12 \mathrm{hr}$} & \multicolumn{1}{c}{$24 \mathrm{hr}$} \\
\hline $3 \mu \mathrm{g} / \mathrm{ml}$ & $97.3 \pm 6.2$ & $93.8 \pm 6.5$ \\
$6 \mu \mathrm{g} / \mathrm{ml}$ & $101.2 \pm 5.5$ & $98.0 \pm 5.8$ \\
$9 \mu \mathrm{g} / \mathrm{ml}$ & $96.0 \pm 6.7$ & $107.5 \pm 5.7$ \\
$12 \mu \mathrm{g} / \mathrm{ml}$ & $104.7 \pm 7.3$ & $101.9 \pm 9.4$ \\
$15 \mu \mathrm{g} / \mathrm{ml}$ & $91.8 \pm 6.4$ & $92.2 \pm 8.3$ \\
\hline
\end{tabular}

Attachment of precursor cells to substrate-coated L1 at different concentrations 12 and $24 \mathrm{hr}$ after plating in the presence of growth factors. No significant differences were detected between the two substrates at the two time points. Percentages show numbers of attached cells in relation to the PLL substrate, which was set to $100 \%$.

L1 expressed by fibroblasts also enhances neuronal differentiation of precursor cells

To investigate whether L1 exposed on the surface of live cells would also influence proliferation and differentiation of neural precursor cells, embryonic murine fibroblasts were transfected to express L1 under a bidirectional promotor that also drives the 


\section{A TUNEL-labeling 10 days after plating}
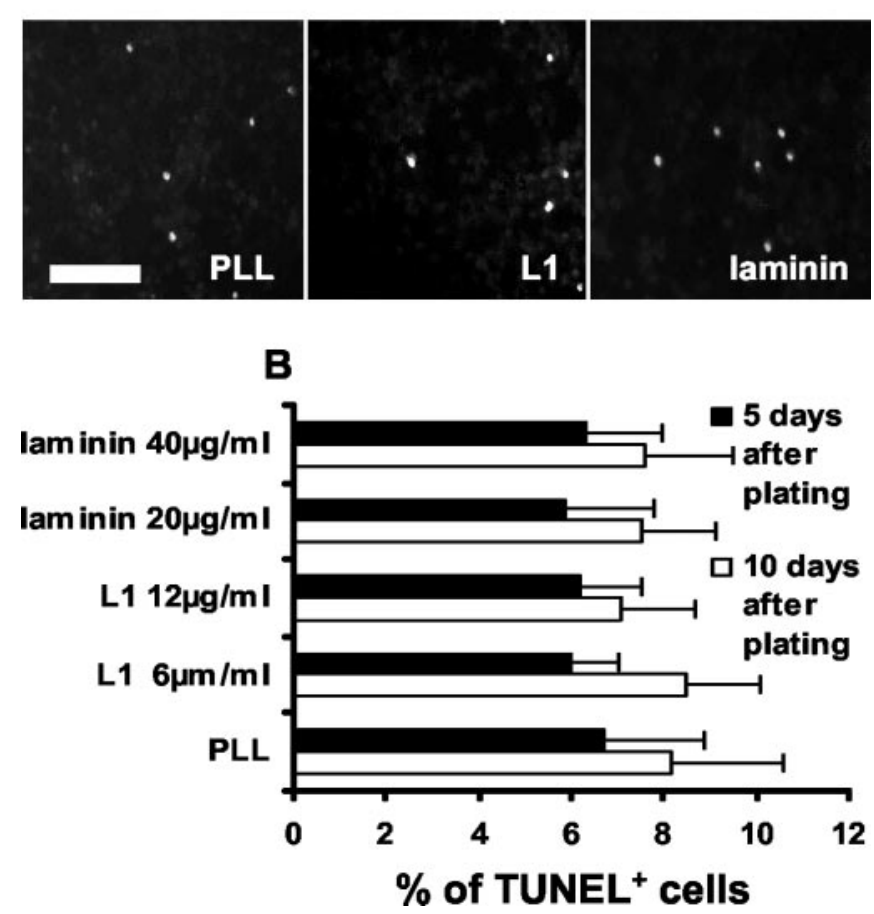

Figure 4. Death of precursor cells on laminin, L1, or PLL substrate, $5 \mathrm{~d}$ after plating with growth factors or $10 \mathrm{~d}$ after plating ( $5 \mathrm{~d}$ without and $5 \mathrm{~d}$ with growth factors) is similar. $A$, TUNEL labeling of precursor cells grown on PLL, L1, or laminin substrate. B, Percentage of TUNEL ${ }^{+}$cells of all cells as detected by DAPI staining. Scale bar, $250 \mu \mathrm{m}$. Values are means + SEM.

luciferase reporter gene (Baron et al., 1995). L1 expression on transfected cells was monitored immunocytochemically and by immunoblotting as well as by determination of luciferase activity (Fig. 5A,B). Twenty of 25 clones, raised from transfected fibroblasts, showed L1 immunoreactivity and a 100-fold increase in luciferase activity in comparison with wild-type fibroblasts. Wild-type fibroblasts and a L1-transfected clone were used to study the effect of L1.

Dissociated precursor cells were grown on a confluent layer of $\mathrm{L}^{+}$or $\mathrm{L}^{-}$fibroblasts in the presence of growth factors. Attachment of precursor cells to $\mathrm{L}^{+}{ }^{+}$or $\mathrm{L}^{-}{ }^{-}$fibroblasts 12 or $24 \mathrm{hr}$ after plating was similar. Ten days after plating (first $5 \mathrm{~d}$ in the presence of growth factors and then for another $5 \mathrm{~d}$ in their absence), the percentage of $\beta$-tubulin ${ }^{+}$neurons was $4.8 \pm 0.6$-fold higher on $\mathrm{L}^{+}$fibroblasts than on $\mathrm{L}^{-}{ }^{-}$fibroblasts (Fig. $6 A, A^{\prime}, D$ ). The percentage of $\mathrm{GFAP}^{+}$astrocytes decreased by $41 \pm 4.2 \%$ on $\mathrm{L}^{+}$ fibroblasts when compared with $\mathrm{L} 1^{-}$fibroblasts (Fig. $6 B, B^{\prime}, D$ ). The percentage of $\mathrm{MAG}^{+}$oligodendrocytes was not influenced by $\mathrm{L}^{+}$fibroblasts (Fig. $6 C, C^{\prime}, D$ ). As measured by BrdU incorporation $5 \mathrm{~d}$ after precursor cells were seeded in the presence of growth factors, proliferation of precursor cells tended to be lower on $\mathrm{L}^{+}{ }^{+}$fibroblasts but was not significantly different from proliferation on $\mathrm{L1}^{-}$fibroblasts (Fig. $6 \mathrm{E}$ ). Interestingly, precursor cell proliferation on fibroblasts was reduced by $\sim 40 \%$ in comparison with the PLL substrate.

L1-induced changes in precursor cell development are caused by heterophilic interaction

Having shown that L1 influences precursor cell proliferation and differentiation, we investigated whether homophilic or heterophilic interactions with L1 are involved. Although precursor cells

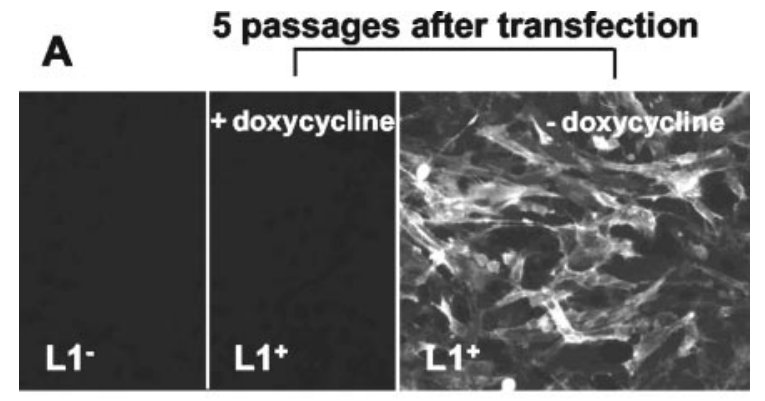

B 5 passages after transfection

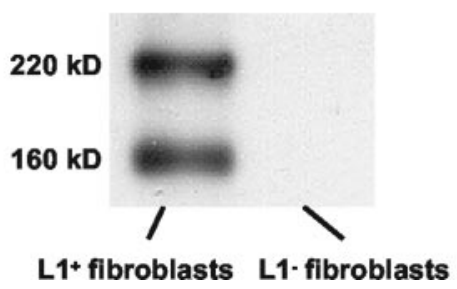

Figure 5. Regulated L1 expression by transfected murine fibroblasts under control of a tetracycline derivative. $A$, As detected by immunocytochemistry, neither parental fibroblasts $\left(\mathrm{L}^{-}\right)$nor L1-transfected fibroblasts $\left(\mathrm{L1}^{+}\right)$in the presence of doxycycline express $\mathrm{L} 1$. In the absence of doxycycline, $\mathrm{L} 1$-transfected fibroblasts were $\mathrm{L} 1^{+}$. $B$, As detected by immunoblotting, L1 expression was seen in transfected fibroblasts in the absence of doxycycline but not in parental cells. The two L1 bands are detected at 220 and $160 \mathrm{kDa}$.

do not immunocytochemically express L1 (see first paragraph in Results) and only become $\mathrm{L}^{+}$after differentiation into $\beta$-tubulin ${ }^{+}$neurons, low levels of L1 expression cannot be excluded. To investigate whether heterophilic interactions are involved, precursor cells of L1-deficient mice were generated and compared with those generated from wild-type mice. When grown under identical culture conditions and on identical substrates, no differences in diameter of neurospheres or proliferation and differentiation of precursor cells generated from L1deficient or wild-type mice could be detected (Fig. 7A-C). Inhibition of proliferation on substrate-coated L1 was similar between precursor cells derived from L1-deficient and wild-type mice (Fig. 7B). Furthermore, generation of $\beta$-tubulin ${ }^{+}$neurons from L1-deficient stem cells was enhanced by $2.2 \pm 0.2$-fold on L1 substrate and by $4.5 \pm 0.5$-fold on $\mathrm{Ll}^{+}$fibroblasts in comparison with PLL substrate or $\mathrm{L1}^{-}$fibroblasts. Generation of GFAP ${ }^{+}$ astrocytes from L1-deficient precursor cells was reduced by $34 \pm$ $3.5 \%$ on $\mathrm{L} 1$ substrate and by $38 \pm 4.3 \%$ on $\mathrm{L}^{+}{ }^{+}$fibroblasts when compared with PLL substrate or $\mathrm{L}^{-}{ }^{-}$fibroblasts. We conclude that L1 influences neural precursor cell proliferation and differentiation by heterophilic interaction via a yet unknown receptor or receptors.

$\mathbf{L} 1$ influences differentiation of $\boldsymbol{\beta}$-tubulin ${ }^{+}$neurons into different neurotransmitter phenotypes

To investigate whether L1 may influence the differentiation of precursor cell-derived neurons into a particular neurotransmitter phenotype, immunocytochemistry was performed with markers for GABAergic neurons (GAD), catecholaminergic neurons (TH), and cholinergic neurons (VAChT). Double immunocytochemistry was performed with antibodies against $\beta$-tubulin and the neurotransmitter-specific markers after different time periods of culture (up to $20 \mathrm{~d}$ after starting differentiation), and in the following, percentages of neurotransmitter-specific marker-expressing neurons among all $\beta$-tubulin ${ }^{+}$neurons are 

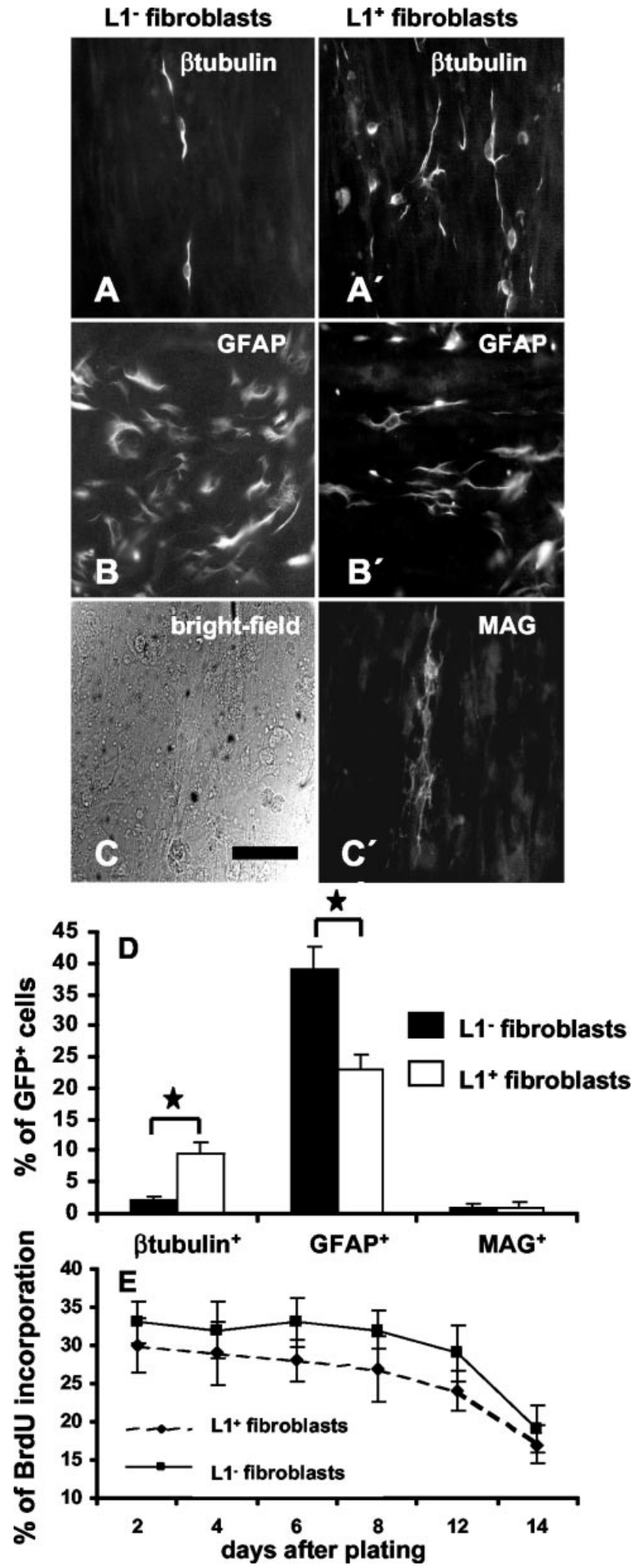

Figure 6. L1 expressed by fibroblasts influences proliferation and differentiation of precursor cells. Precursor cells were plated on a monolayer of parental or L1-expressing fibroblasts. Immunofluorescence photomicrographs of $\beta$-tubulin ${ }^{+}$neurons $\left(A, A^{\prime}\right)$ and GFAP ${ }^{+}$astrocytes $\left(B, B^{\prime}\right)$ on parental or L1-expressing fibroblasts. $C, C^{\prime}$, Bright-field photomicrograph of the fibroblasts monolayer and corresponding MAG immunocytochemistry. Scale bar, $50 \mu \mathrm{m}$. $D$, Percentage of $\beta$-tubulin ${ }^{+}-\mathrm{GFP}^{+}, \mathrm{GFAP}^{+}{ }_{-} \mathrm{GFP}^{+}$, and $\mathrm{MAG}^{+}{ }_{-} \mathrm{GFP}^{+}$precursor cells $10 \mathrm{~d}$ after plating on parental or L1-expressing fibroblasts. $E$, BrdU incorporation of precursor cells grown on parental or L1-expressing fibroblasts is given for different time points after plating. Values are means + SEM. ${ }^{*} p<0.05$ versus the indicated bar.

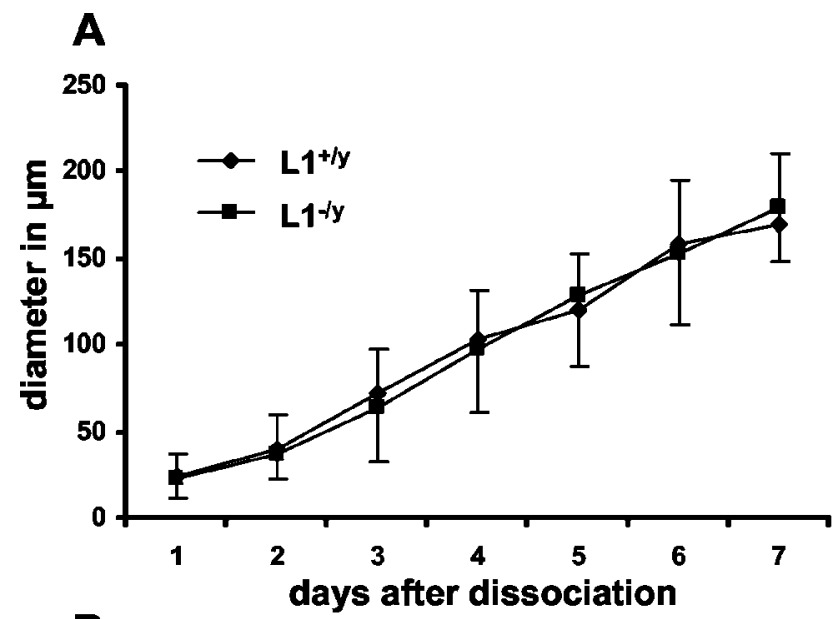

B
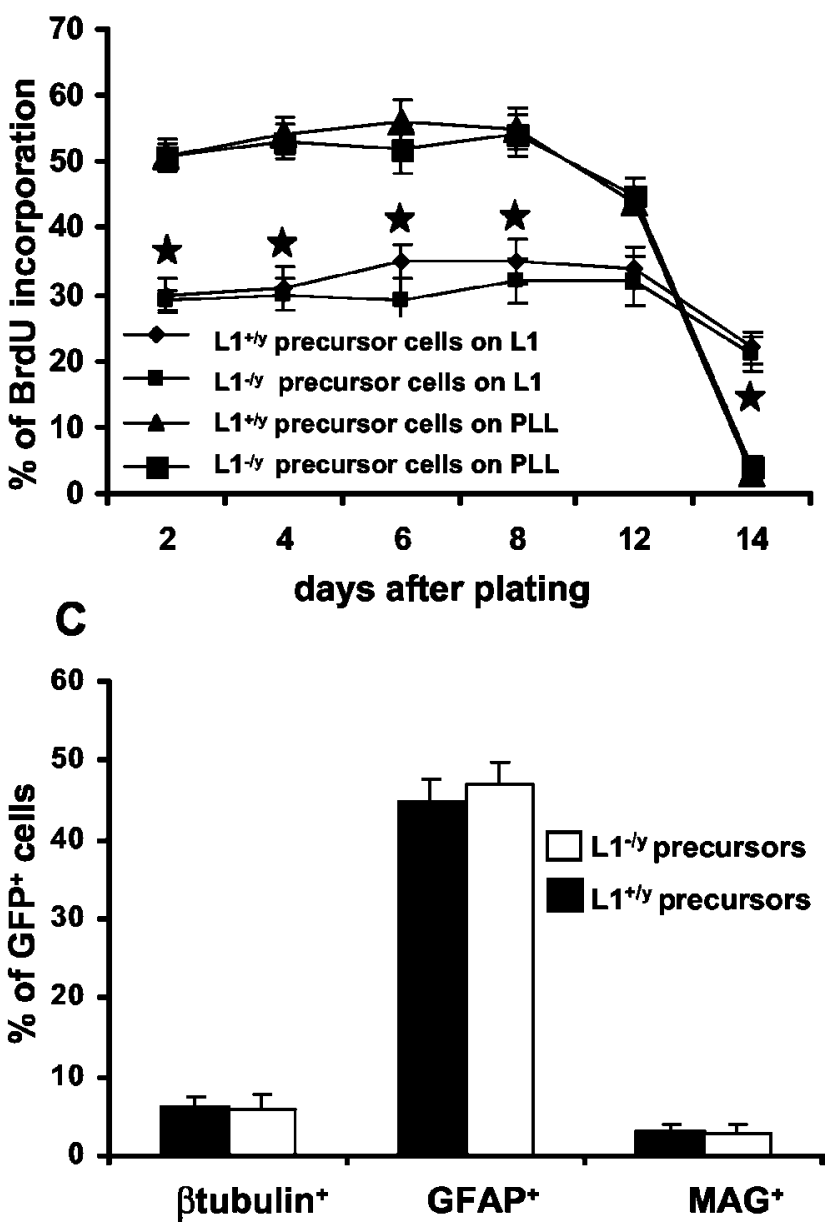

Figure 7. Precursor cells generated from L1-deficient mice. A-C, Sphere diameter, proliferation, and differentiation of precursor cells generated from L1-deficient mice are similar when compared with precursor cells from wild-type mice. $A$, Diameter of neurospheres from L1-deficient or wild-type mice. $B$, Percentages of BrdU ${ }^{+}$precursor cells from L1-deficient or wild-type mice cultured on PLL or L1 substrates are given for different time points after plating. C, Percentage of cell type-specific marker expression in precursor cell-derived descendents from L1-deficient or wild-type mice. ${ }^{*} p<0.05$ versus the corresponding time point on PLL substrate.

given. All neurotransmitter-specific marker-expressing neurons were also $\beta$-tubulin ${ }^{+}$. Under the conditions of our study, $\mathrm{TH}^{+}$ neurons were detectable only occasionally, on PLL as well as on L1 substrate. However, generation of cholinergic (Fig. 8A) and GABAergic (Fig. $8 B$ ) neurons was influenced significantly by L1. 

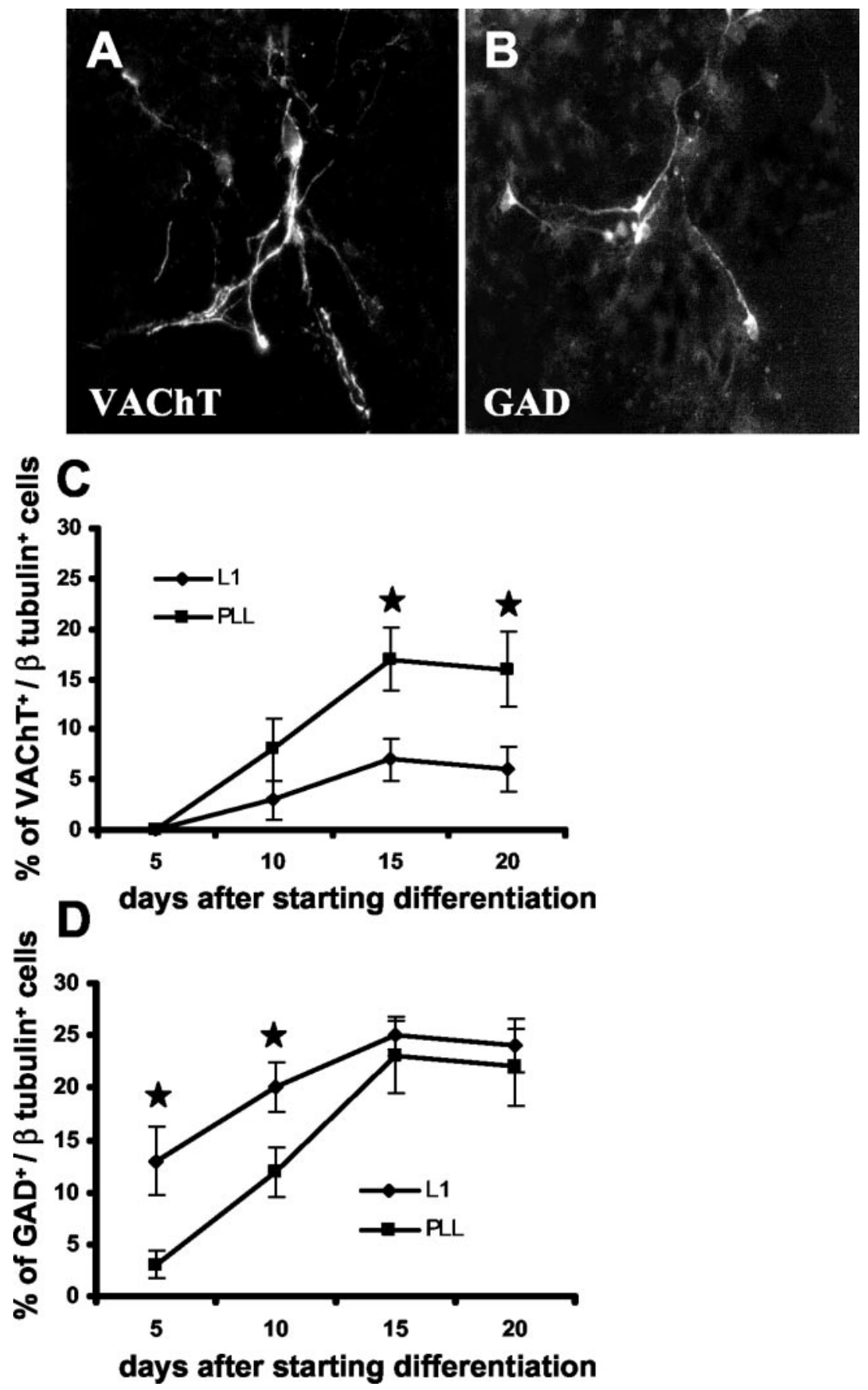

Figure 8. Generation of different neuronal subtypes from neural precursor cells over a time period of $20 \mathrm{~d}$. $A-C$, Immunocytochemistry for vesicular acetylcholine transporter (VAChT) for cholinergic neurons and glutamate dehydrogenase (GAD) for GABAergic neurons. Time course of the percentage of VAChT (D) or GAD $(E)$ expression of all $\beta$-tubulin ${ }^{+}$neurons over a time period of $20 \mathrm{~d}$ after starting differentiation on PLL or L1 $(6 \mu \mathrm{g} / \mathrm{ml})$ substrate. Scale bar, $15 \mu \mathrm{m} .{ }^{*} p<0.05$ versus the corresponding time point on PLL substrate.

Five days after starting differentiation, only very few cholinergic neurons were detected on PLL or L1 substrate. Ten days after starting differentiation, more cholinergic neurons were detectable on PLL substrate than on L1 substrate. This difference became significant at 15 and $20 \mathrm{~d}$ after starting differentiation (Fig. $8 C$ ). At these time points, $\sim 61 \%$ fewer cholinergic neurons were detected on L1 than on PLL substrate.

GABAergic neurons were already detected in higher amounts $5 \mathrm{~d}$ after starting differentiation, with $4.3 \pm 0.4$ times more GABAergic neurons on L1 than on PLL substrate (Fig. $8 D$ ). Ten days after starting differentiation, the percentage of GABAergic neurons was higher than after $5 \mathrm{~d}$ on PLL and L1, with neurons plated on L1 showing $1.7 \pm 0.5$ times more GABAergic phenotypes than those on PLL substrate. Fifteen and $20 \mathrm{~d}$ after starting differentiation, the percentage of GABAergic neurons plated on PLL was approximately equal to that on L1 substrate.

To control for possible differences in cell densities between precursors maintained on PLL or L1 substrate, precursor cells on L1 substrate were allowed to proliferate for an additional $3 \mathrm{~d}$. When equal cell densities were reached ( $5 \mathrm{~d}$ on PLL and $8 \mathrm{~d}$ on L1 substrate), both cultures were allowed to differentiate for $10 \mathrm{~d}$ without growth factors. Even with identical cell densities, differences in percentages of cholinergic neurons $(15.3 \pm 2.1 \%$ on PLL; $8.6 \pm 1.8 \%$ on L1) and GABAergic neurons $(10.6 \pm 1.9 \%$ on PLL; $19.5 \pm 2.4 \%$ on L1) were seen. When precursor cells were maintained at higher concentrations of substrate-coated L1 ( 9 and $12 \mu \mathrm{g} / \mathrm{ml}$ ), results were similar to those obtained with coating concentrations of $6 \mu \mathrm{g} / \mathrm{ml} \mathrm{L1}$ (data not shown). Furthermore, L1 exposed on the cell surface of fibroblasts also influenced neurotransmitter-specific maturation of $\beta$-tubulin ${ }^{+}$neurons. Precursor cells were grown on $\mathrm{L}^{+}{ }^{+}$or $\mathrm{L}^{-}$fibroblasts for $10 \mathrm{~d}$ after starting differentiation with a reduction of cholinergic neurons $\left(19.0 \pm 2.7 \%\right.$ on $\mathrm{Ll}^{-}$fibroblasts; $8.7 \pm$ $1.8 \%$ on $\mathrm{L}^{+}$fibroblasts) and an increase in GABAergic neurons $(9.9 \pm 2.5 \%$ on $\mathrm{L} 1^{-}$fibroblasts; $21.7 \pm 2.8 \%$ on $\mathrm{L}^{+}{ }^{+}$fibroblasts). Heat inactivation of L1 abolished the effects of $\mathrm{L} 1$ on neuronal subtype-specific differentiation.

To investigate whether neurotransmitter-specific differentiation of neurons was caused by homophilic or heterophilic L1 interactions, experiments were performed with precursor cells from L1deficient mice seeded on PLL or L1 substrate. Substrate-coated L1 did not influence the neurotransmitter-specific maturation of precursor-derived neurons from L1-deficient mice ( $\mathrm{L1}^{-}$GABAergic neurons- $\beta$-tubulin ${ }^{+}$neurons on PLL: $10.5 \pm 2.0 \%$; on L1 substrate: $12.3 \pm 2.3 \%$; $\mathrm{L}^{-}{ }^{-}$cholinergic neurons- $\beta$-tubulin ${ }^{+}$neurons on PLL: $18.6 \pm$ $2.8 \%$; on L1 substrate: $21.4 \pm 3.2$ ). There was no difference between the percentage of GABAergic or cholinergic neurons among all $\beta$-tubulin ${ }^{+}$neurons generated from either L1deficient or wild-type precursor cells when grown on PLL substrate ( $\mathrm{L}^{-}{ }^{-}$GABAergic neurons- $\beta$-tubulin ${ }^{+}$neurons on PLL: $10.5 \pm 2.0 \% ; \mathrm{L}^{+}{ }^{+}$GABAergic neurons- $\beta$-tubulin ${ }^{+}$neurons on PLL: $11.8 \pm 1.6$; $\mathrm{L1}^{-}$cholinergic neurons- $\beta$-tubulin ${ }^{+}$neurons on PLL: $18.6 \pm 2.8 \%$; $\mathrm{L}^{+}{ }^{+}$cholinergic neurons- $\beta$-tubulin ${ }^{+}$neu- 
rons on PLL: $16.9 \pm 2.9$ ). These observations indicate that L1 expression by immature neurons and L1 as substrate are necessary for the reduction in neurons undergoing cholinergic differentiation. Thus, neurotransmitter-specific differentiation depends on L1 homophilic or L1 coreceptor-mediated interactions between substrate-coated L1 and L1 expressed on the cell surface of differentiating immature neurons.

L1 inhibits proliferation of monopotential, bipotential, and multipotential precursor cell clones To investigate whether the increased number of neurons after precursor cell differentiation on the L1 substrate might be caused by selectively enhanced proliferation of neuronal precursors versus an inhibited proliferation of glial precursor cells, a clonal analysis was performed. First, we compared the number of cells within different types of clones (monopotential, bipotential, and multipotential) derived from single neural precursor cells. Both monopotential neuronal clones and monopotential astrocytic clones showed a significant reduction in cell number of $46 \%(p<0.01)$ or $38 \%(p<0.05)$, respectively, when grown for $15 \mathrm{~d}$ on the L1 substrate in comparison with PLL or laminin substrates (Fig. 9A,B). This observation rules out the possibility that enhanced proliferation of monopotential neuronal but not glial precursor cells leads to the overall increased percentage of neurons in differentiated cultures. This conclusion is supported further by the observation that the number of proliferating neuronal precursors identified immunocytochemically by $\mathrm{BrdU}^{+}-\mathrm{pGp}^{+}$double labeling is decreased on the L1 substrate (data not shown). Also the bipotential (Fig. 10A-C) and multipotential (Fig. $10 \mathrm{D}$ ) clones proliferated less when grown on an L1 substrate compared with PLL or laminin substrates. To rule out possible differences in the extent of cell death when comparing different clone types and different substrates, quantification of TUNEL-positive cells within monopotential neuronal or astrocytic clones was performed. No significant differences in number of TUNELpositive cells on different substrates were detected (data not shown).

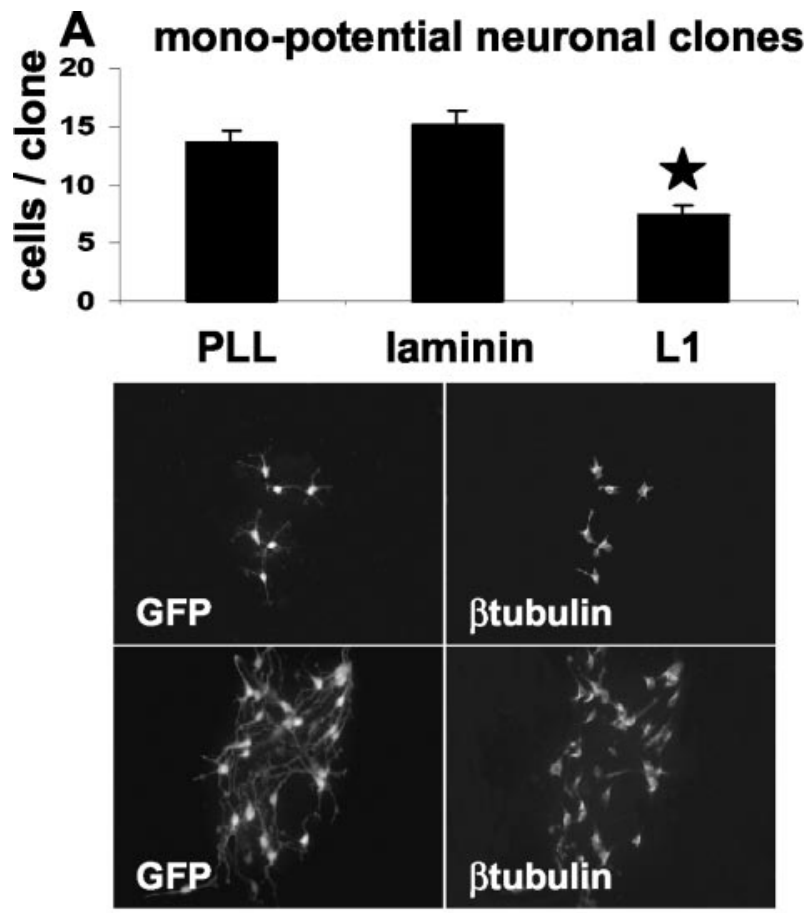

neuronal clone on L1-substrate

neuronal clone on PLL-substrate

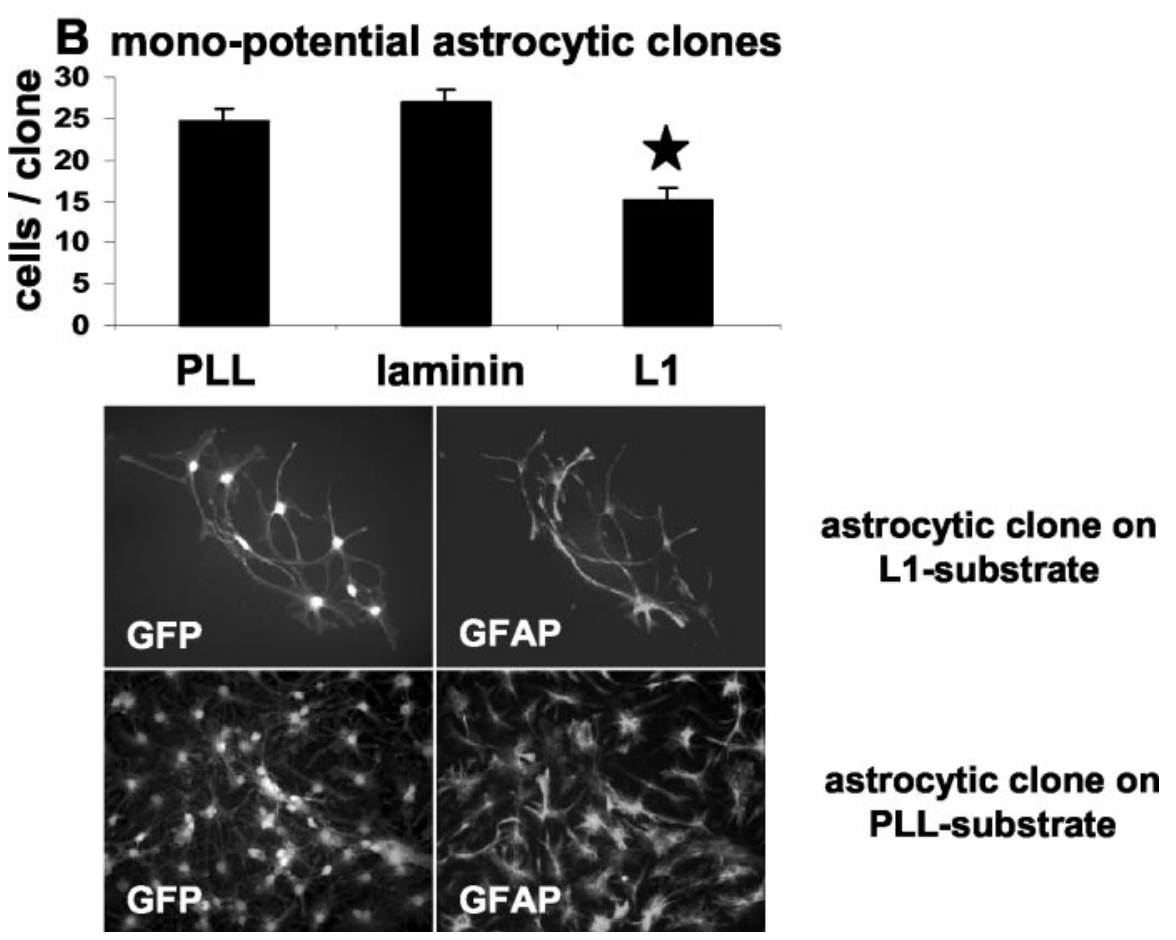

Figure 9. L1 inhibits proliferation of monopotential neuronal or astrocytic clones. The number of cells within individual monopotential neuronal $(A)$ or astrocytic $(B)$ clones was determined after clones were maintained for $15 \mathrm{~d}$ on PLL, laminin, or L1 substrates. Diagrams indicate the averaged number of cells per clone. Left and right photomicrographs show representative GFP-labeled neuronal $(A)$ and astrocytic $(B)$ clones on L1 or PLL substrates. Clone type was assessed by triple-label immunocytochemistry for $\beta$-tubulin (Cy3), GFAP (Cy5), and MBP (UV). Only clones derived from single GFP ${ }^{+}$cells were considered for clonal analysis. Values are means $+\mathrm{SEM} .{ }^{*} p<0.05$ versus the corresponding clone type on laminin or PLL.

L1 influences selectively the neuronal differentiation of precursor cells within multipotential and bipotential neuronastrocyte clones

To assess whether the increased number of neurons on the L1 substrate is caused by changes in the proportion of different cell types only within certain clone types, we determined the percent- age of neurons, astrocytes, and oligodendrocytes within individual bipotential and multipotential clones. Indeed, L1 increased selectively the percentage of neurons in neuron-astrocyte bipotential clones (2.8-fold versus PLL substrate, $p<0.05$; 2.1 -fold versus laminin substrate, $p<0.05)$ and in multipotential clones (3.9-fold versus PLL substrate, $p<0.001 ; 3.2$-fold versus laminin 

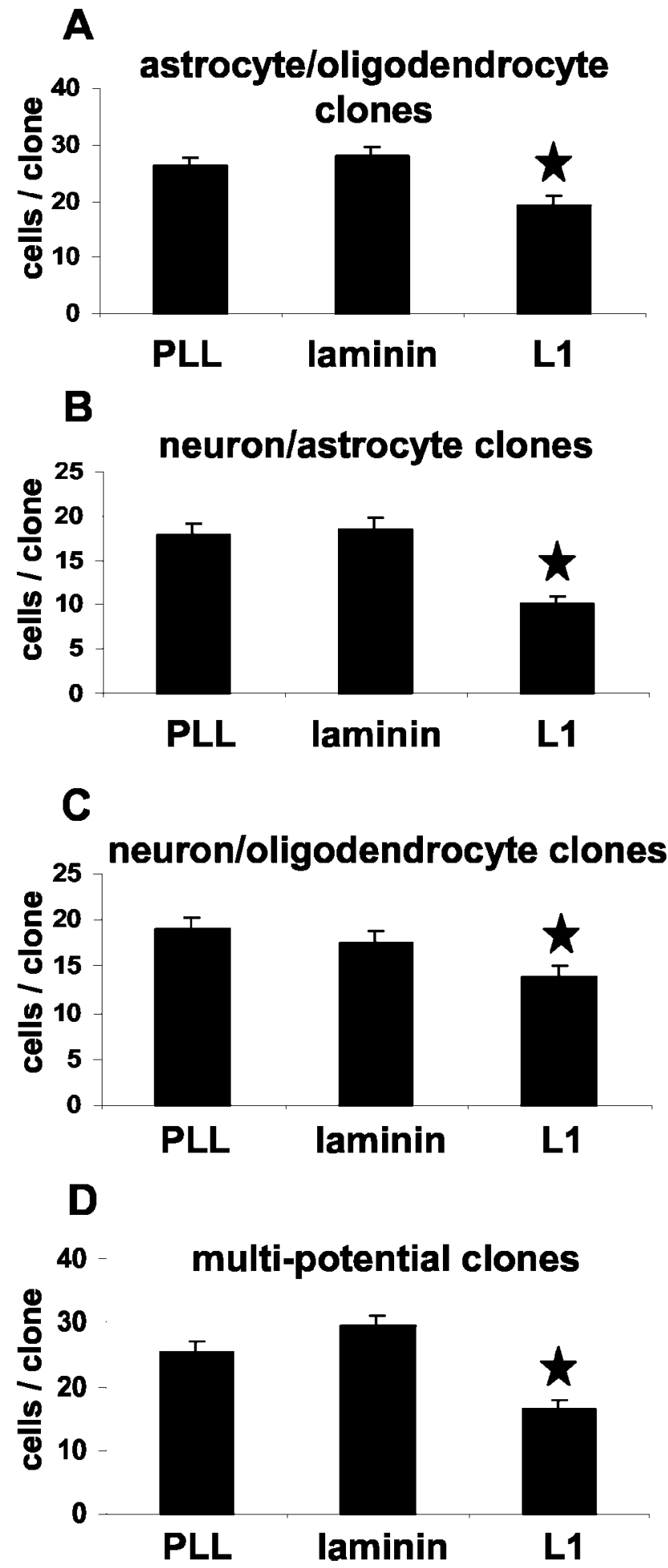

Figure 10. $\quad$ L1 inhibits proliferation of bipotential $(A-C)$ and multipotential $(D)$ clones. The number of cells within individual clones was determined after clones were maintained for $15 \mathrm{~d}$ on PLL, laminin, or L1 substrates. Diagrams indicate the averaged number of cells per clone. Values are means + SEM. ${ }^{*} p<0.05$ versus the corresponding clone type on laminin and PLL.

substrate, $p<0.001$ ) (Fig. 11). The neuron-oligodendrocyte ratio in bipotential neuron-oligodendrocyte clones was not influenced by L1. Thus, when the uncloned population was assayed for neuronal differentiation (see above), it is the neuronal precursor pool derived from multipotential and bipotential neuronastrocyte precursors that is responsible for the overall twofold (in comparison with PLL, $p<0.05$ ) and 1.9-fold (in comparison with laminin, $p<0.05$ ) increase in number of neurons after maintenance on the L1 substrate for $10 \mathrm{~d}$.

L1 does not change the initial lineage potential of individual precursor cells

To investigate whether the commitment of the different monopotential, bipotential, and multipotential precursor cells is stable after maintaining single cells for $15 \mathrm{~d}$ on L1, laminin, or PLL substrates, quantification of different clone types on different substrates was performed. No differences were detected concerning the proportion of different clone types on different substrates (Fig. 12). Thus, L1 does not appear to influence the initial lineagepotential of the monopotential, bipotential, and multipotential clones but modulates their ensuing individual lineage decision.

\section{Discussion}

Our present study demonstrates that the cell adhesion molecule L1 modifies neural precursor cell proliferation, differentiation, and neuronal subtype-specific development, first via heterophilic mechanisms and then via a homophilic or L1 coreceptormediated interaction. L1 inhibits proliferation of different precursor cell types cultured in the presence of growth factors via heterophilic interactions. After precursor cell differentiation is initiated, L1 enhances neuronal differentiation and inhibits astrocytic differentiation, also via heterophilic interactions. During differentiation of precursor cells into mature neurons, L1 inhibits maturation of cholinergic neurons and accelerates maturation of GABAergic neurons. This effect depends on the presence of homophilic L1 or L1 coreceptor-dependent mechanisms. The rare event of maturation into dopaminergic neurons was not influenced by L1 under our culture conditions. In contrast to L1, the extracellular matrix molecule laminin did not influence precursor cell proliferation and differentiation significantly when compared with poly-L-lysine, which was used as reference in this study.

L1 inhibits in a dose-dependent manner precursor cell proliferation in the presence of EGF and FGF. Because L1 does not change the percentage of TUNEL ${ }^{+}$precursor cells in comparison with laminin or PLL, reduction of proliferation is not caused by apoptosis. Because the anti-proliferative effect of L1 was detected over a culture period of 2 weeks after plating, cell density does not appear to play a role. In contrast to the anti-proliferative effect of substrate-coated $\mathrm{L} 1, \mathrm{~L}_{1}{ }^{+}$fibroblasts tended to but did not significantly decrease proliferation of precursor cells in comparison with $\mathrm{L}^{-}$fibroblasts. However, precursor cell proliferation was in general significantly lower when cultured on fibroblasts, independent of their L1 expression, and thus it is possible that a fibroblast-induced inhibition of precursor proliferation reduces the contribution of L1. Because the anti-proliferative effect of substrate-coated L1 is clearly dose dependent, it is also conceivable that L1 is not expressed in sufficient amounts on the surface of fibroblasts to influence precursor cell proliferation. However, because the amount of $\mathrm{L} 1$ expressed on fibroblasts is sufficient to enhance neurogenesis, the former explanation appears more reasonable. Although substrate-coated L1 was able to decrease precursor cell proliferation, precursors did not differentiate as long as growth factors were present. Thus, L1 can counteract the proliferative effect of growth factors but cannot initiate differentiation in the presence of growth factors.

Substrate-coated L1 led to an approximately twofold higher number of $\beta$-tubulin ${ }^{+}$neurons after differentiation when compared with PLL substrate. In addition, the number of $\mathrm{GFAP}^{+}$ 
astrocytes was reduced by $\sim 33 \%$. Differentiation experiments with different cell densities and at different days after plating revealed that the $\mathrm{L} 1$ effect is independent of cell density or culture time. Because laminin had no comparable influence on precursor cell differentiation, a general effect of molecules that enhance cell adhesion can be ruled out. L1 exposed on the surface of fibroblasts led to a 4.8 -fold increase of $\beta$-tubulin ${ }^{+}$neurons in comparison with wild-type fibroblasts, and thus the enhancement of neuronal differentiation by $\mathrm{L}^{+}$fibroblasts was more than twofold higher in comparison with that obtained by substrate-coated L1 (2.0-fold on L1-substrate vs 4.8-fold on $\mathrm{L}^{+}{ }^{+}$fibroblasts). Higher amounts of L1 on the cell surface of transfected fibroblasts than on the substrate as a possible explanation seems unlikely, because higher concentrations of substrate-coated L1 $(>6 \mu \mathrm{g} / \mathrm{ml})$ did not further enhance neuronal differentiation. A more reasonable explanation for the stronger effect of membrane-bound L1 on neuronal differentiation is that interaction of $\mathrm{L} 1$ with its receptor(s) is more efficient when $\mathrm{L} 1$ is exposed at the surface of a viable cell. In addition, these experiments show that fibroblast-exposed L1 is able to predominate over other fibroblastexposed and -derived factors in enhancing neuronal differentiation. In contrast to the increased neuronal differentiation, the decreased astrocytic differentiation seems to be independent of the way L1 is presented, because the decrease of GFAP ${ }^{+}$cells by membrane-bound L1 (41\%) was comparable with that caused by substrate-coated L1 (33\%). This points to the possibility that neuronal and astrocytic differentiation can be influenced independently of each other.

Different mechanisms by which L1 influences the generation of $\beta$-tubulin ${ }^{+}$neurons and $\mathrm{GFAP}^{+}$astrocytes are possible (Rao, 1999; Morrison, 2001). Because it has been shown that different factors may selectively influence proliferation and death of lineage-restricted precursor cell types before differentiation and, thus, influence percentages of neurons and astrocytes (Lillien, 1998), a clonal analysis was performed. In all monopotential, bipotential, and multipotential precursor cell clones analyzed, L1 decreased the proliferation independent of cell type. It is noteworthy that the percentage of proliferating neuronal precursors detected immunocytochemically by BrdU-pGp 9.5 double labeling was also decreased by L1. Thus, L1 does not selectively enhance proliferation of neuronal precursors, which could have been an explanation for the increased percentage of neurons found after maintaining the precursor cells on L1.

Another possibility by which the percentages of neurons and astrocytes may be influenced is to promote survival or to inhibit apoptosis of a particular subgroup of cells (Kirschenbaum and Goldman, 1995; Wade et al., 1999). Because L1 promotes neuronal survival (Chen et al., 1999), it is likely that this may account for the increased proportion of neurons after precursor cell differentiation. However, TUNEL staining revealed that there is no significant difference in overall precursor cell death on different substrates either during proliferation ( $5 \mathrm{~d}$ after plating) or during

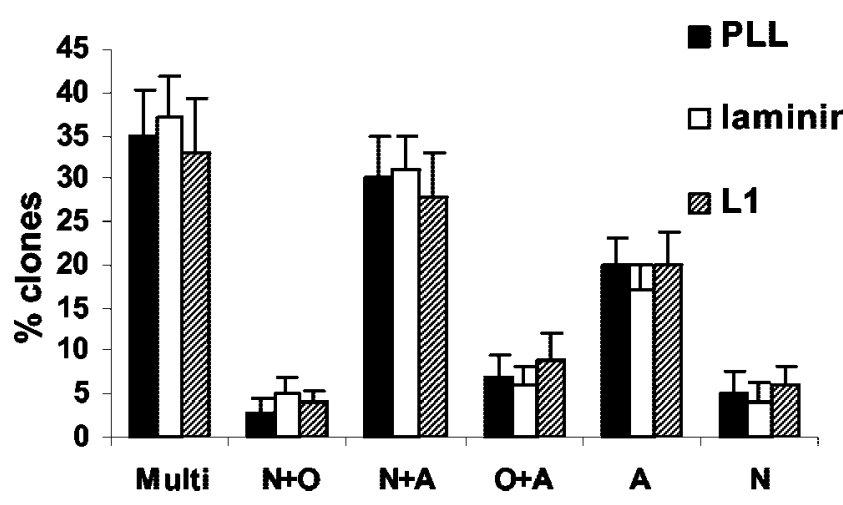

Figure 12. Percentages of different clone types on PLL, laminin, or L1 substrate. After precursor cells were maintained on PLL, laminin, or L1 substrates for $15 \mathrm{~d}$, the distribution of different clone types was scored for each substrate. No significant differences were found between different substrates. Values are means + SEM. Clone types were as follows: Multi, multipotential; $\mathrm{N}+0$, neuronoligodendrocyte bipotential; $\mathrm{N}+\mathrm{A}$, neuron-astrocyte bipotential; $0+A$, oligodendrocyte-astrocyte bipotential; A, astrocytic monopotential; N, neuronal monopotential.

differentiation (10 d after plating). In addition, no differences in the percentage of TUNEL ${ }^{+}$cells within monopotential clones on different substrates were found, indicating that L1 does not influence survival of monopotential neuronal or astrocytic precursors. Furthermore, because only very few $\beta$-tubulin ${ }^{+}$neurons or $\mathrm{GFAP}^{+}$astrocytes were also TUNEL ${ }^{+}$(mostly undifferentiated nestin ${ }^{+}$precursors were $\mathrm{TUNEL}^{+}$), it is unlikely that L1 selectively influences cell death or cell survival of already committed or differentiated precursor cell-derived descendants.

A third possibility by which the percentages of neurons and 
astrocytes may be influenced on the L1 substrate is an instructive role in lineage decision. This instructive role for $\mathrm{L} 1$ is most likely, because L1 does not increase proliferation or reduce apoptotic cell death. This possibility is supported by the observation that enhanced neuronal differentiation selectively occurs within multipotential and neuron-astrocyte bipotential clones but not within neuron-oligodendrocyte bipotential clones.

The interrelationship between proliferation and differentiation of stem cells remains tentative so far, because a reduction in proliferation does not mean that stem cells automatically start to differentiate and lose multipotentiality (Morshead and van der Kooy, 1992; Morrison et al., 1997). This is fitting with our observation that $\mathrm{L} 1$ is able to decrease proliferation of stem cells in the presence of growth factors but is not able to initiate differentiation in the presence of growth factors. It is thus unlikely that L1 regulates differentiation indirectly via reducing proliferation. Rather, it appears that proliferation and differentiation are independent processes and that L1 exerts an instructive role on precursor cells toward neuronal differentiation.

This apparent instructive role of L1 for neuronal differentiation might be an explanation for the reduced number of hippocampal neurons in L1-deficient mice (Demyanenko et al., 1999). Newly generated cells from the subgranular layer migrate in the dentate gyrus, which expresses L1 during the period in which the majority of granule cells are born in the wild-type mouse (Gould et al., 1991). During this time, proliferation and differentiation of precursor cells might be modified by L1. To evaluate this possibility, endogenous neurogenesis must be measured in wild-type and L1-deficient mice with the determination of precursor proliferation and neuron-glia production.

It has been reported that the neural cell adhesion molecule (NCAM) reduces proliferation of hippocampus-derived precursor cells and enhances neuronal differentiation (Amoureux et al., 2000). In contrast to L1, however, NCAM initiates differentiation in the presence of growth factors. It is interesting that the percentage of neurons in the study by Amoureux and colleagues (2000) is generally higher than in our study, possibly indicating that hippocampus-derived precursor cells prefer the neuronal lineage when compared with the precursor cells generated from the ganglionic eminence in our study. It is conceivable, therefore, that hippocampus-derived precursor cells may have already been committed to a neuronal lineage before explantation (Seaberg and van der Kooy, 2002). This interpretation remains tentative, however, because a clonal analysis was not performed in this study.

L1 influences neural precursor cell proliferation and differentiation via heterophilic interactions, because our data show that precursor cells derived from L1-deficient mice also were inhibited in proliferation and enhanced in neuronal differentiation by substrate-coated or membrane-bound L1. Because L1 has been shown to bind heterophilically to recognition molecules such as F3-F11-contactin, CD24, and integrins (Brümmendorf and Rathjen, 1993; Ruppert et al., 1995; Montgomery et al., 1996), these molecules, if expressed by differentiating neural precursor cells, may act as heterophilic signal transducers at the neuronal cell surface. Expression of integrins on neural precursor cells has been described (Jacques et al., 1998); however, more indirect mechanisms involving secondary mediators are also conceivable.

In contrast to heterophilic influences on precursor cell proliferation and differentiation, the transmitter subtype of precursor cell-derived neurons was influenced only if L1 was present both in the substrate and on immature neurons. This constellation is consistent with a possible homophilic interaction between exog- enous and endogenous L1, but also with a heterophilic interaction between exogenous L1 and a so far unknown coreceptor for L1 that depends on endogenous L1 for signal transduction. Although 5 and $10 \mathrm{~d}$ after starting differentiation no significant differences were detected between cholinergic neurons on PLL or L1 substrate, 15 and $20 \mathrm{~d}$ after starting differentiation percentages of cholinergic neurons were significantly lower on L1 substrate. Furthermore, the L1 substrate accelerates maturation of GABAergic neurons, because percentages of GABAergic neurons 5 and $10 \mathrm{~d}$ after starting differentiation on L1 substrate were higher when compared with PLL substrate. However, 15 and $20 \mathrm{~d}$ after starting differentiation, no significant differences in percentages of GABAergic neurons on L1 or PLL substrates could be detected, indicating that L1 merely accelerates GABAergic differentiation. These effects were independent of the form of presentation of L1, whether substrate coated or surface membrane bound. Interestingly, we only occasionally observed dopaminergic neurons, independent of whether precursors were cultured on PLL or L1 substrate. The fact that L1 is first expressed on postmitotic neurons points to the interesting possibility that the neurotransmitter subtype decision is made, at least under the circumstances of our study, after a cell has begun to differentiate into a neuron. During CNS development, L1 thus could influence neural precursors sequentially. First, L1 could act via heterophilic action on multipotential and bipotential precursor cells and then via homophilic or L1 coreceptor-mediated mechanisms on immature neurons that start to express L1. The mechanisms by which L1 influences transmitter subtype-specific differentiation of neurons remain to be investigated.

\section{References}

Amoureux MC, Cunningham BA, Edelman GM, Crossin KL (2000) $\mathrm{N}$-CAM binding inhibits the proliferation of hippocampal progenitor cells and promotes their differentiation to a neuronal phenotype. J Neurosci 20:3631-3640.

Baron U, Freundlieb S, Gossen M, Bujard H (1995) Co-regulation of two gene activities by tetracycline via a bidirectional promoter. Nucleic Acids Res 23:3605-3606.

Bjorklund A (1999) The use of neural stem cells for gene therapy in the central nervous system. J Gene Med 1:223-226.

Bjorklund A (2000) Cell replacement strategies for neurodegenerative disorders. Novartis Found Symp 231:7-15.

Bjorklund A, Lindvall O (2000) Cell replacement therapies for central nervous system disorders. Nat Neurosci 3:537-544.

Brümmendorf T, Rathjen FG (1993) Axonal glycoproteins with immunoglobulin- and fibronectin type III-related domains in vertebrates: structural features, binding activities, and signal transduction. J Neurochem 61:1207-1219.

Brümmendorf T, Kenwrick S, Rathjen FG (1998) Neural cell recognition molecule L1: from cell biology to human hereditary brain malformations. Curr Opin Neurobiol 8:87-97.

Brüstle O, Spiro AC, Karram K, Choudhary K, Okabe S, McKay RD (1997) In vitro-generated neural precursors participate in mammalian brain development. Proc Natl Acad Sci USA 94:14809-14814.

Brüstle O, Jones KN, Learish RD, Karram K, Choudhary K, Wiestler OD, Duncan ID, McKay RD (1999) Embryonic stem cell-derived glial precursors: a source of myelinating transplants. Science 285:754-756.

Campbell K, Olsson M, Bjorklund A (1995) Regional incorporation and site-specific differentiation of striatal precursors transplanted to the embryonic forebrain ventricle. Neuron 15:1259-1273.

Chen S, Mantei N, Dong L, Schachner M (1999) Prevention of neuronal cell death by neural adhesion molecules L1 and CHL1. J Neurobiol 38:428-439.

Dahme M, Bartsch U, Martini R, Anliker B, Schachner M, Mantei N (1997) Disruption of the mouse L1 gene leads to malformations of the nervous system. Nat Genet 17:346-349.

Demyanenko GP, Tsai AY, Maness PF (1999) Abnormalities in neuronal 
process extension, hippocampal development, and the ventricular system of L1 knock-out mice. J Neurosci 19:4907-4920.

Gage FH (1998) Stem cells of the central nervous system. Curr Opin Neurobiol 8:671-676.

Gossen M, Bujard H (1992) Tight control of gene expression in mammalian cells by tetracycline-responsive promoters. Proc Natl Acad Sci USA 89:5547-5551.

Gould E, Woolley CS, McEwen BS (1991) Naturally occurring cell death in the developing dentate gyrus of the rat. J Comp Neurol 304:408-418.

Hortsch M (1996) The L1 family of neural cell adhesion molecules: old proteins performing new tricks. Neuron 17:587-593.

Hortsch M (2000) Structural and functional evolution of the L1 family: are four adhesion molecules better than one? Mol Cell Neurosci 15:1-10.

Jacques TS, Relvas JB, Nishimura S, Pytela R, Edwards GM, Streuli CH, ffrench-Constant C (1998) Neural precursor cell chain migration and division are regulated through different betal integrins. Development 125:3167-3177.

Kintner C (2002) Neurogenesis in embryos and in adult neural stem cells. J Neurosci 22:639-643.

Kirschenbaum B, Goldman SA (1995) Brain-derived neurotrophic factor promotes the survival of neurons arising from the adult rat forebrain subependymal zone. Proc Natl Acad Sci USA 92:210-214.

Lillien L (1998) Neural progenitors and stem cells: mechanisms of progenitor heterogeneity. Curr Opin Neurobiol 8:37-44.

Lundberg C, Martinez-Serrano A, Cattaneo E, McKay RD, Bjorklund A (1997) Survival, integration, and differentiation of neural stem cell lines after transplantation to the adult rat striatum. Exp Neurol 145:342-360.

Montgomery AM, Becker JC, Siu CH, Lemmon VP, Cheresh DA, Pancook JD, Zhao X, Reisfeld RA (1996) Human neural cell adhesion molecule L1 and rat homologue NILE are ligands for integrin alpha v beta 3. J Cell Biol 132:475-485.

Morrison SJ (2001) Neuronal potential and lineage determination by neural stem cells. Curr Opin Cell Biol 13:666-672.
Morrison SJ, Shah NM, Anderson DJ (1997) Regulatory mechanisms in stem cell biology. Cell 88:287-298.

Morshead CM, van der Kooy D (1992) Postmitotic death is the fate of constitutively proliferating cells in the subependymal layer of the adult mouse brain. J Neurosci 12:249-256.

Morshead CM, van der Kooy D (2001) A new "spin" on neural stem cells? Curr Opin Neurobiol 11:59-65.

Okabe M, Ikawa M, Kominami K, Nakanishi T, Nishimune Y (1997) "Green mice" as a source of ubiquitous green cells. FEBS Lett 407:313-319.

Poltorak M, Sadoul R, Keilhauer G, Landa C, Fahrig T, Schachner M (1987) Myelin-associated glycoprotein, a member of the L2/HNK-1 family of neural cell adhesion molecules, is involved in neuron-oligodendrocyte and oligodendrocyte-oligodendrocyte interaction. J Cell Biol 105:1893-1899.

Rao MS (1999) Multipotent and restricted precursors in the central nervous system. Anat Rec 257:137-148.

Rathjen FG, Schachner M (1984) Immunocytological and biochemical characterization of a new neuronal cell surface component (L1 antigen) which is involved in cell adhesion. EMBO J 3:1-10.

Ruppert M, Aigner S, Hubbe M, Yagita H, Altevogt P (1995) The L1 adhesion molecule is a cellular ligand for VLA-5. J Cell Biol 131:1881-1891.

Schachner M (1989) Families of neural adhesion molecules. Ciba Found Symp 145:156-169.

Seaberg RM, van der Kooy D (2002) Adult rodent neurogenic regions: the ventricular subependyma contains neural stem cells, but the dentate gyrus contains restricted progenitors. J Neurosci 22:1784-1793.

Senner V, Kismann E, Puttmann S, Hoess N, Baur I, Paulus W (2002) L1 expressed by glioma cells promotes adhesion but not migration. Glia $38: 146-154$.

Wade SB, Oommen P, Conner WC, Earnest DJ, Miranda RC (1999) Overlapping and divergent actions of estrogen and the neurotrophins on cell fate and p53-dependent signal transduction in conditionally immortalized cerebral cortical neuroblasts. J Neurosci 19:6994-7006. 